\title{
The Applicability of Microbially Induced Calcite Precipitation (MICP) for Internal Erosion Control in Gravel-Sand Mixtures
}

\section{Ning-Jun Jiang, BEng ${ }^{1 *}$ and Kenichi Soga, PhD FREng FICE ${ }^{2}$}

\begin{abstract}
Seepage-induced internal erosion in earth-filled embankment dams has been attracting attentions of civil engineering researchers and practitioners for decades. Microbially induce carbonate precipitation (MICP), due to its proved performance in soil enhancement and permeability control, can be potentially used for internal erosion control. This paper examines the applicability of MICP for internal erosion control in gravel-sand mixtures using a large one-dimensional column test apparatus which incorporates the implementation of MICP. Visual obersverations, erosion characteristics and hydromechanical behaviours of Non-MICP and MICP treated gravel-sand mixtures were investigated through a series of constant-pressure erosion tests. Test results confirm that MICP treatment can reduce the cumulative erosion weight, erosion rate and axial strain relative to Non-MICP soil. The magnitudes of hydraulic conductivity for all tested samples before erosion process fall into a range from $5.5 \times 10^{-5}$ to $8.0 \times 10^{-3} \mathrm{~m} / \mathrm{s}$. After erosion process, Non-MICP soils and MICP treated soils with low cementation concentrations experience a significant increase in the hydraulic conductivity. Furthermore, the hydro-mechanical coupling analysis was conducted and different erosion modes were identified for low and high concentrations of cementation solution, respectively. Fundamentally, the efficiency of internal erosion reduction is controlled by the calcium carbonate precipitation content within the tested soils. Higher precipitation content can facilitate the formation of larger clusters of cemented sand particles, thus reducing the likelihood of erosion.
\end{abstract}

\footnotetext{
${ }^{1} \mathrm{PhD}$ candidate, Department of Engineering, University of Cambridge, Trumpington Street, Cambridge, CB2 1PZ, UK. (*Corresponding author) Email: jiangningjun@gmail.com; nj263@cam.ac.uk.

${ }^{2}$ Professor, Department of Civil and Environmental Engineering, University of California-Berkeley, Berkeley, CA 94720, USA. Email: soga@berkeley.edu
} 


\section{Introduction}

Seepage-induced internal erosion or piping in earth-filled embankment dams has been attracting attentions of civil engineering researchers and practitioners for decades. It is reported that internal erosion induced collapse is the third most important mode for earth dam failure after overtopping and external erosion, and it accounts for $\sim 14.3 \%$ of all dam failures (Danka and Zhang 2015). Internal erosion, if initiated and progressed, would trigger associated adverse alternations in physical (e.g., grain size distribution), hydraulic (e.g., permeability) and mechanical (e.g., undrained and drained strength) behaviours of soils composing the dam cores (Chang and Zhang 2013a; Correia dos Santos et al. 2015; Moffat et al. 2011). The understanding of the internal erosion phenomena primarily relies on experimental investigations (Fannin and Slangen 2014). Early attempts focused on the effect of grain size distribution on the erosion potential of soils, usually conducted using in-house permeameter at different scales. Particle geometric relations were proposed accordingly as the criteria for internal stability of soils (Chang and Zhang 2013b; Kenney and Lau 1985; Kézdi 1979; Li and Fannin 2008). The importance of hydro-mechanical coupling phenomena in the course of internal erosion was then acknowledged and led to a large number of studies on the hydraulic criteria for erosion initiation. Hydraulic parameters such as critical hydraulic gradient $\left(i_{c r}\right)$ and critical shear stress $\left(\tau_{c r}\right)$ were adopted to evaluate the hydraulic resistance of tested soils to seepage induced internal erosion (Indraratna et al. 2008; Moffat and Fannin 2011; Reddi et al. 2000). The changes in contractive characteristics, axial strain, secant stiffness, peak deviator stress, and drained and undrained strength were widely identified during the internal erosion process under various hydraulic conditions, mostly in the triaxial cell test apparatus (Chang and Zhang 2013a; Ke and Takahashi 2014, 2015).

Most experimental research on internal erosion process used homogenous or mixed soils with one-dimensional flow in columns (Ouyang and Takahashi 2016; Fleshman and Rice 
2014). Some sophisticated tests were also conducted recently as attempts to better represent the erosion process in real dams. For example, Correia dos Santos et al. (2015) constructed a column soil sample with three zones representing the upstream, core and downstream materials. Richards and Reddy (2012) created a two-dimensional flow net within gap-graded soil samples to simulate the flow field within real dams. Planès et al. (2016) constructed a scaled canal embankment, which was tested to failure by internal erosion in an indoor laboratory.

The prevention of internal erosion within earth-filled dams can be achieved by zoning of the dam (Foster et al. 2000), construction of filters (USBR 1999), chemical stabilization (Indraratna et al. 2008), and other embankment design and foundation treatment measures (Fell et al. 2005). More specifically, the mitigation measures may include: (1) chimney filter drain within dam cores; (2) horizontal filter drain; (3) upstream low permeability blanket; (4) permeable downstream zone; (5) slurry trench in the foundation; (6) chemical grouting in the embankment and foundation; and (7) weighting berm on the downstream slopes.

Microbially induced carbonate precipitation (MICP) is an emerging bio-mineralization technique, which has been extensively investigated for its applicability in geotechnical, environmental and energy engineering (Cheng et al. 2014; Chu et al. 2013; Al Qabany and Soga 2013; Jiang et al. 2016a, b). MICP involves the process of ureolysis by the urease enzyme sythensized through bacteria metabolic activities. Associated alkalinity accumulation at the proximity of bacteria cells triggers the formation of calcite precipitation on nucleation sites (i.e. bacteria cell surfaces) in the presence of available calcium source (DeJong et al. 2010; Ferris et al. 2004). The produced calcite precipitation preferentially accumulate around particle-particle contacts (Al Qabany et al. 2012). Because of this preference of cementation at pore throat locations, large pores are kept relatively open so that the change in permeability is rather small even though soil stiffness and strength are enhanced (Dawoud et al. 2014; 
Martinez et al. 2013; Whiffin et al. 2007). This is an attractive feature of MICP for internal erosion control.

Based on Hammes and Verstraete (2002) and De Muynck et al. (2010), the whole bacteria cell becomes encapsulated by precipitated calcite during the MICP process, which limits the nutrient transfer and results in the cell death. Therefore, the bacteria may not stay alive after the completion of the MICP test. Even if there are still some bacteria alive, Sporosarcina pasteurii (S. pasteurii) is classified as a bioagent on Biosafety Level 1 (BSL-1) based on the criteria developed by US Centers for Disease Control and Prevention (CDCP 2009). It means that $S$. pasteurii is not known to cause disease in healthy adult humans, and of minimal potential hazard to laboratory personnel and the environment. Therefore, no foreseen environment and health risk concerns exist for this particular microbial species. However, the ureolytic MICP process also involves the generation of ammonium ions. Therefore, if the MICP is used for the field application in the future, the generation, transportation and fate of ammonium ions must be well address.

A study of MICP for internal erosion control in sand-clay mixtures has been performed by the authors (Jiang et al. 2016a). In the current study, the applicability of MICP for internal erosion mitigation in gravel-sand mixtures was investigated using a large one-dimensional column test apparatus which incorporates the implementation of MICP. Erosional, geomechanical, and hydraulic behaviours were analysed to evaluate the efficiency of MICP treatment on internal erosion control. Although there have been many previous studies of MICP strengthened soils, this study intends to show the potential benefit of the MICP treatment for gap-graded soils, which may result from the particle segregation during embankment construction. The target of the MICP treatment here is not to improve the strength of the treated soil, but to reduce erodibility while keeping the permeability of the treated soil almost constant. The findings in this study may provide an alternative solution for 
internal erosion problems and show the potential of MICP for full-scale application in the future.

It should be noted that the parellel samples were not tested in the current study. This is because that the nature of observed internal erosion in this study was described primarily from interpretation of erosional behaviour, axial displacement and hydraulic conductivity, which were verified by visual observations. The response of each soil was described herein with reference to a single combination of test variables, thereby providing a detailed illustration of the effect of MICP on internal erosion control.

\section{Testing apparatus}

A large one-dimensional column internal erosion simulator combined with a MICP implementation unit was designed for the current study. The overall schematic is shown in Fig. 1. This test apparatus is composed of a pressurized chamber, an axial loading system, a hydraulic control system, a sanding collection system, a MICP implementation system, and an instrumentation system.

The pressurised chamber is composed of a Perspex hollow column and aluminium pedestal/top plates. The hollow column has a height of $700 \mathrm{~mm}$, an inner diameter of $240 \mathrm{~mm}$, and a thickness of $5 \mathrm{~mm}$. The pedestal features a funnel shaped cavity in the centre to facilitate the transport of sand particles during the test, as shown in Fig. 2(a). A specially designed double-layer base mesh is installed between the pedestal and the Perspex column (Fig. 2(b)), which can provide sufficient rigidity under the gravity of the soil while effectively allow only sand passing through. The gap between the top plate and Perspex column is sealed by a conventional O-ring.

The axial loading system is composed of a porous loading plate, a pneumatic cylinder, an air pressure regulator, and an iron reaction frame. The porous loading plate, as shown in Fig. 
2(c), features a grid of holes to allow for the water dissipation. The leakage between the piston rod and the top plate is prevented via a three-layer sealing, as shown in Fig. 2(d). On the top of the piston connects a pneumatic cylinder via a ball bearing. The pneumatic cylinder, which mounts in the reaction frame, can provide a downward force up to $1.2 \mathrm{kN}$. The applied force can be adjusted accordingly through an air pressure regulator, which maintains a constant pressure during the test.

The hydraulic system functions via a water pressure regulator, which can maintain a constant hydraulic pressure up to $100 \mathrm{kPa}$. A top mesh with an opening size smaller than the sand particles is placed between the porous loading piston and tested soil to evenly distribute the inflow water.

The sanding collection system consists of several $1000 \mathrm{~mL}$ Erlenmeyer flasks. The outflow containing fluidised sands from the outlet of the erosion test apparatus is collected periodically. The particle-containing solution collected by the Erlenmeyer flasks is subject to solid-liquid separation afterwards.

The MICP implementation system is composed of three buckets, each with a volume of 30 L. The distilled water, bacteria solution and cementation solution inside each bucket can be alternatively pumped into the hollow column to complete the soil saturation and biomineralisation processes. The buckets are refilled periodically.

The instrumentation devices employed in this study include six pressure transducers (PT) (maximum: $100 \mathrm{kPa}$; accuracy: $0.1 \mathrm{kPa}$ ), a differential pressure transducer (DPT) (maximum: $100 \mathrm{kPa}$; accuracy: $0.1 \mathrm{kPa}$ ), and a linear variable displacement transducer (LVDT) (maximum: $100 \mathrm{~mm}$; accuracy: $0.1 \mathrm{~mm}$ ). More specifically, two PTs (PT-0 and PT-5) are connected to the inlet and outlet pipes while the other four are affixed to the wall of the hollow column. The distances from the bottom of the tested soil to the four PTs are 100, 200, 300, and $400 \mathrm{~mm}$, respectively. The DPT connects the inlet and outlet pipes directly to 
measure the overall pressure loss along the whole soil column. The LVDT is mounted on the loading piston rod to measure the axial displacement. Readings of these measuring devices are acquired through analog input channels of a Measurement Computing ${ }^{\text {TM }}$ data acquisition system and written to a digital storage using a USB interface and the TracerDAQ software on a laptop. Data are recorded at a frequency of $1 \mathrm{~Hz}$ (once per second).

\section{Testing materials and procedures}

\section{Testing materials}

Tested soil

Core Materials in embankment dams and levees are built using broadly graded soil to avoid seepage-induced internal erosion. In dam construction, core materials are usually placed by scrapers or dumped from a truck and spread with a grader or bulldozer (Milligan 2003). However, if gravel-sized fill materials are allowed for construction, segregation is likely to happen. This is because that dumped from a truck, and spread by a grader or bulldozer may result in the coarser particles lying at the base of the layer, and the fines on the surface. The rolling compaction may further break the upper part of the layer, creating even more segregation (Fell et al. 2005). Segregation can result in severe internal erosion and piping with the dams, thus requiring effective countermeasures.

In this study, a gap-graded granular soil was created by mixing a natural gravel soil with a British Standard graded sand (Fraction D, supplied by David Ball Group plc). The particle size distributions of the gravel and sand are shown in Fig. 3. The gravel and sand were mixed at a ratio of 1:1 based on dry weight (i.e. sand content 50\%). Based on Vallejo (2001), the gravel-sand binary mixture is classified as the transitional fine grain supported structure. Standard proctor compaction test gives the result that the binary mixture has a maximum dry density $\left(\gamma_{\mathrm{d} \text {,max }}\right)$ of $18.6 \mathrm{kN} / \mathrm{m}^{3}$ and optimum water content $\left(w_{\mathrm{opt}}\right)$ of $9.1 \%$. The binary mixture 
is categorised as gap graded soil based on the criteria proposed by Lafleur et al. (1989). Internal erosion potential analysis was conducted for this binary mixture based on the method proposed by Kenney and Lau (1986). The stability index (H/F), which is the ratio between mass fraction at any grain size $d(\mathrm{~F})$ and mass fraction between grain size $d$ and $4 d(\mathrm{H})$, was calculated for this binary mixture. The $(\mathrm{H} / \mathrm{F})_{\min }$ of the gravel-sand mixture in this study is only 0.15 , significantly less than 1.0 , which is the threshold for internal stability (Kenney and Lau 1986). Thus, this binary mixture is deemed to be highly susceptible to the seepageinduced internal erosion.

\section{Bacteria and cementation solution}

S. pasteurii (ATCC 6452), a urease-active strain was used in this study, due to its welldefined urease-synthesis behaviour and superior urease activity over many other alternative urease-producing bacteria (Seagren and Aydilek 2010). This bacterium strain was rehydrated under a sterile aerobic batch condition in the solid $\mathrm{NH}_{4}$-YE medium (see Table 1). After 24 hours of incubation at $30^{\circ} \mathrm{C}$, the culture was harvested and stored at $4{ }^{\circ} \mathrm{C}$. Before the MICP treatment, bacteria colonies extracted from the solid $\mathrm{NH}_{4}$-YE medium was transferred into eight sterilised Erlenmeyer flasks, each containing $500 \mathrm{~mL}$ of urea-rich $\mathrm{NH}_{4}$-YE solution medium (see Table 1) and placed in a shaking incubator for 24 hours. The cultivated bacteria solution $(4 \mathrm{~L})$ was then diluted to $12 \mathrm{~L}$ using the clean urea-rich $\mathrm{NH}_{4}$-YE solution medium. The optical density at $600 \mathrm{~nm}\left(\mathrm{OD}_{600}\right)$ of the final solution ready for test is $0.454 \pm 0.137$, which is slightly lower than with those reported in previous studies (Cheng et al. 2014; Al Qabany and Soga 2013). The lower cell concentration in the final solution is mainly attributed to the dilution effect. The average measured specific urease activity $(1.012 \pm 0.390$ $\mathrm{mM}$ urea $\mathrm{min}^{-1} \mathrm{OD}^{-1}$ ), however, is sufficient to induced ureolytic reactions (Whiffin 2004). 
The composition and concentration of the cementation solution used in the current study is shown in Table 1 as well. The selected concentrations $(0.2 \mathrm{M}, 0.4 \mathrm{M}, 0.6 \mathrm{M}, 1.0 \mathrm{M}$ and 2.0 M) cover the range adopted in most previous studies that showed effective MICP treatment (DeJong et al. 2014; Montoya et al. 2013; Al Qabany and Soga 2013).

\section{Testing methods}

\section{Soil preparation and MICP treatment}

The soil specimen preparation procedure is shown in Fig. 4. Firstly, the hollow column, pedestal and bottom mesh were assembled. Then the dry gravel and sand were mixed thoroughly at the $w_{\mathrm{opt}}$, using either distilled water in the Non-MICP case or the cementation solution in the MICP treatment case. The moist mixed soil was then compacted in six layers with the target of $95 \%$ degree of compaction (the actual achieved degree of compaction is $93 \%$ through weight and volume measurements). After the compaction was completed, the surface of the compacted soil was carefully levelled and the top mesh and porous plate were placed. The entire hollow column was finally sealed by the top plate, with the sealing between piston rod and top plate in place as well. With LVDT attached, the pneumatic cylinder was connected to the piston rod. A constant axial stress of $24 \mathrm{kPa}$ (in terms of the cross-section area of the soil column) was then applied by the pneumatic cylinder. Soil column was then saturated under a constant hydraulic head of $0.1 \mathrm{~m}$ via upflowing water in the non-MICP case and bacteria solution in the MICP treatment case. The axial displacement monitored via LVDT confirmed that no significant disturbance occurred during the saturation procedure. The satiated soil column was then subject to the internal erosion test immediately in the nonMICP case while was retained for the MICP reaction for another 24 hours prior to the erosion test in the MICP treatment case. The 24-hour for the MICP reaction was selected based on existing studies on the ureolytic reaction kinetics. Actually, Michaelis-Menten equation (or 
modified one) has been extensively used in characterising the ureolytic reaction kinetics of $S$. pasteurii (Fidaleo and Lavecchia 2003; Lauchnor et al. 2015). The kinetic parameters from these studies have all demonstrated that the ureolytic reaction can be completed within a few minutes to hours (significantly less than 24 hours) for the cementation concentrations covered in this study $(0.2 \mathrm{M}$ to $2.0 \mathrm{M})$. The nucleation and crystal growth of calcite precipitation may take extra time beyond the ureolytic reaction. However, this process mainly depends on the chemical properties of solution (e.g., $\mathrm{pH}$ and supersaturation state) and the equilibrium can be reached very quickly under a certain solution chemical condition. In most previous studies, reaction time less than 24 hours was adopted after the injection of bacteria and cementation solutions (Al Qabany et al. 2012; Martinez et al .2013; Lin et al. 2016).

It should be noted that the MICP implementation method designed in the current study attempts to simulate the potential field trial of MICP during the construction of new earthfilled embankment dams or levees. In this scenario, the cementation solution is mixed with the in-situ soil composing the dam core and foundation, and then is subject to the compaction via a roller. The bacteria solution prepared in-situ is implemented from the upstream side during the first impoundment after the completion of the dam.

\section{Internal erosion test}

The satiated compacted gravel-sand mixtures, with or without MICP treatment, were subject to the downward internal erosion test under constant hydraulic pressures. The specifications for the internal erosion test are shown in Table 2. The internal erosion test was initiated via applying the constant hydraulic pressure from the top plate. The selection of hydraulic pressure, as specified in Table 2, is to address a wide range of erosion severity. Then, the outlet valve was opened and the outflow containing sand particles were collected by the Erlenmeyer flasks periodically as specified in Table 2. The collection time for each Erlenmeyer flask was 30 s. The flow rate was measured based on the volume of the outflow 
collected at 30s periodically. The liquid-solid partition was done after collection to facilitate the volume measurements. The entire internal erosion test lasted for 30 mins, during which the axial displacement, overall pressure loss along the soil length, and pore pressures at different locations were recorded accordingly. The 30-min testing time was selected to restrict the excessive axial displacement in the worst case which might be beyond the measurement range of LVDT. For most of the MICP treated samples, it is found that no further erosion and axial displacement occurred after $20 \mathrm{~min}$. Therefore, the testing time of 30 min was sufficient for the erosion process to complete. After the termination of the internal erosion test, the soil column was cut into four equal slides, each of which was subject to sieving via a $2 \mathrm{~mm}$ mesh to determine the remaining sand contents at different locations. Photos were taken immediately after the internal erosion test to facilitate visual check of the erosion severity.

In this study, the calcite precipitation content within the MICP treated samples that were not subject to the erosion process was determined at various locations via the shaking chamber method, as specified in Jiang et al. (2016a).

It should be noted that all the MICP treatment and erosion tests were conducted in a constant-temperature room at $20^{\circ} \mathrm{C}$.

\section{Results and data interpretation}

The results of the internal erosion tests for gravel-sand mixtures were analysed by comparing the MICP treated and untreated samples from the following four aspects: 1) visual observations; 2) erosion characterisation; 3) geomechanical behaviours; and 4) hydraulic responses.

Visual observation 
Visual observation has been adopted extensively as a qualitative tool for the internal erosion characterisation (Correia dos Santos et al. 2015; Moffat et al. 2011; Ouyang and Takahashi 2015, 2016). Fig. 5 shows the photos taken after the completion of the internal erosion tests for both the Non-MICP and MICP treated soils. For all Non-MICP samples, it is obvious to see that higher imposed hydraulic pressure induces more severe erosion patterns. At $30 \mathrm{kPa}$ of hydraulic pressure, a through-washout zone of the sand was clearly identified. For the case of MICP-0.2M, no significant surface washout zone was spotted at low hydraulic pressure. However, a significant axial settlement was observed at $30 \mathrm{kPa}$ of hydraulic pressure. When the cementation concentration rises to $0.4 \mathrm{M}$, only slight axial settlement was identified at $30 \mathrm{kPa}$ of hydraulic pressure while no any surface erosion was seen by naked eyes. Eventually, cementation concentrations higher than $0.4 \mathrm{M}$ correspond to no visually discernible erosion, regardless of the imposed hydraulic pressure.

\section{Erosion characterisation}

The erosion severity is usually directly estimated by the weight or erosion rate of eroding particles (Indraratna et al. 2015; Ke and Takahashi 2015). In the current study, the weight of flushed sand particles was measured periodically to determine the erosion rate and cumulative erosion weight. Fig. 6 (a) shows the evolution of the cumulative erosion weight with time. It is found that, for the cases of Non-MICP, MICP-0.2M, and MICP-0.4M, higher imposed hydraulic pressure induces more cumulative erosion weight with time. At the hydraulic pressure lower than $20 \mathrm{kPa}$, the treatment with $0.2 \mathrm{M}$ cementation solution can reduce the ultimate erosion percentage to less than 5\%, as shown in Fig. 6(a). However, at 30 $\mathrm{kPa}$ of hydraulic pressure, at least $0.4 \mathrm{M}$ cementation is needed to bring down the ultimate erosion percentage to less than 5\%. With higher cementation concentrations, the cumulative erosion weight is negligible even at the maximum imposed hydraulic pressure. In particular, 
the sample with $2.0 \mathrm{M}$ cementation can resist $50 \mathrm{kPa}$ of hydraulic pressure without noticeable erosion.

It should be noted that the sample of MICP-0.2M_30kPa has less resistance to internal erosion than the sample of Non-MICP-30kPa. It is attributed to the fact that the way that bacteria was percolated into the samples might disturb the soil structure and create some internal flaws prior to the internal erosion test. At high hydraulic pressure (i.e., $30 \mathrm{kPa}$ ), these internal flaws are severely developed to form preferential paths, which was observed from Fig. 5. This further reduces the erosion-resistance of the sample of MICP-0.2M_30kPa, making it lower than that of the sample of Non-MICP_30kPa. This effect becomes negligible at higher cementation concentration and lower hydraulic pressure.

The ultimate percentage of sand erosion was compared with those measured by Indraratna et al. (2015) and Ke and Takahashi (2015), as marked in Fig. 6(a). The Non-MICP samples in the current study have slightly lower erosion percentages than that reported by Ke and Takahashi (2015). As the initial porosity is around 0.33 in the current study, which is lower than that used by Ke and Takahashi (2015) (0.38-0.40), the slightly higher percentage of sand erosion reported by Ke and Takahashi (2015) may be attributed to its looser soil structure than in the current study. The reason for a lower erosion percentage in the study of Indraratna et al. (2015) is that (1) the grain size distribution of used soil is much more wellgraded than in the current study and (2) an upward erosion test was conducted, which required higher hydraulic pressure to induce erosion than in the current study.

The change of erosion rate with time is shown in Fig. 6(b). Similar to the trend of the cumulative erosion weight, cementation concentration higher than $0.4 \mathrm{M}$ is needed to reduce erosion rate to the negligible level. It is also noticed that erosion rates of all samples, except the cases of Non-MICP_15kPa, Non-MICP_20kPa, Non-MICP_30kPa, and MICP$0.2 \mathrm{M} \_30 \mathrm{kPa}$, peak between $200 \mathrm{~s}$ and $400 \mathrm{~s}$ and eventually drop to the negligible level after 
1200s. This indicates that these samples acquire new equilibriums from then, due to the presence of calcite precipitation. However, all Non-MICP samples fail to establish the new equilibriums, since they cannot reduce the erosion rate to a negligible level even at the completion of the internal erosion tests. It should be noted that the sharp drop of erosion rate after $750 \mathrm{~s}$ in the cases of Non-MICP 30kPa, and MICP-0.2M_30kPa is due to the formation of preferential paths through the soil samples, which can be observed from Fig. 5.

Fig. 7 shows the remaining sand contents from the top to the bottom of the soil samples after the internal erosion tests. All samples except MICP-0.2M_30kPa experience greater erosion at the bottom layers relative to the top ones. This indicates that the sand erosion develops backwards, as it was observed by Bendahmane et al. (2008) and Richards and Reddy (2012). Treatments with cementation concentrations higher than $0.4 \mathrm{M}$ can help to reduce the backwards erosion to the minimum, which is consistent with the results of the cumulative erosion weight.

It should be noted that sand content higher than $50 \%$ in some cases is primarily attributed to the sampling procedure. After the completion of the erosion tests, the gap-graded soil samples become heterogeneous locally. Although special cares have been taken to make sure that sampling is representative (four sub-samples were taken at each layer and mixed to measure the sand content), the measured values might still deviate from the actual values. Even so, it can be seen in Fig. 7 that the sand contents at the top layer of most samples only deviate slightly around $50 \%$, indicating that no significant erosion occurs at the top layer.

\section{Geomechanical responses}

The internal erosion process normally accompanies significant ground settlement. The evolution of the axial displacement with time is illustrated in Fig. 8 (a). It can be found that, with cementation concentration $\leq 0.4 \mathrm{M}$, soil samples display larger axis displacement at 
higher imposed hydraulic pressure. Cementation concentration $>0.4 \mathrm{M}$ can reduce the axis displacement to the negligible level in the course of the entire internal erosion tests. Except for the cases of Non-MICP_15kPa, Non-MICP_20kPa, Non-MICP_30kPa, and MICP$0.2 \mathrm{M} \_30 \mathrm{kPa}$, all samples reach plateau axial displacements before $1250 \mathrm{~s}$, indicating the establishment of new equilibriums, which is consistent with the erosion rate measurement. The ultimate axial strain of the Non-MICP samples measured in the current study is found to be comparable with that reported by Chang and Zhang (2013a) for gap-graded sandy soils under a worse scenario, as shown in Fig. 8 (a). However, it is still larger than that reported by Ke and Takahashi (2014), which is mainly attributed to the higher sand content and lower confining pressure applied in the current study.

Fig. 8 (b) shows the evolution of the overall porosity of gravel-sand mixtures with time. The overall porosity of gravel-sand mixtures was calculated based on the three-phase relationship in the classical soil mechanics. Since the soil has been saturated before the erosion tests, the porosity can be calculated as follows:

$$
\mathrm{n}=\frac{\mathrm{V}_{\mathrm{v}}}{\mathrm{V}}=\frac{\mathrm{V}-\mathrm{V}_{\mathrm{s}}}{\mathrm{V}}=1-\frac{\left(\frac{\mathrm{m}_{\mathrm{g}}}{\mathrm{G}_{\mathrm{sg}}}+\frac{\mathrm{m}_{\mathrm{s}}}{\mathrm{G}_{\mathrm{ss}}}\right) \frac{1}{\rho_{\mathrm{w}}}}{\mathrm{V}}
$$

where $V_{s}$ is the volume of the soil grains, $V_{v}$ is the volume of voids, $V$ is the total volume, $m_{g}$ is the weight of gravel, $m_{s}$ is the weight of sand, $G_{s g}$ is the specific gravity of gravel (2.65), $G_{s s}$ is the specific gravity of sand (2.65), and $\rho_{w}$ is the unit weight of water. By measuring the changes in the sample height and the weight of sand loss, the changes in porosity can be obtained accordingly. It should be noted that the calculated values only reflect the overall soil sample properties. The heterogeneity during the erosion process may significantly affect the local porosity. 
It is found that the loss of sand particles can result in the increase in the overall porosity while the bulk axial deformation leads to its reduction. In Fig. 8 (b), all the Non-MICP samples experience reduction in porosity at the initial 250s. This indicates that the Non-MICP samples are dominated by the axial deformation instead of the particle loss at this early stage. Later, the Non-MICP samples display substantial increase in the overall porosity due to a large amount of sand loss. The MICP treatment with cementation concentration $\geq 0.4 \mathrm{M}$ contributes to the significant reduction in the porosity change relative to the Non-MICP samples. The overall porosity change becomes negligible when cementation concentration is larger than $0.6 \mathrm{M}$, which is consistent with the results of the erosion weight and the axial deformation.

\section{Hydraulic responses}

The change in the pore pressure within the gravel-sand mixture samples is an indicator of hydraulic responses due to the MICP treatment. Fig. 9 shows the evolution of pore pressures at four locations within three representative samples (MICP-2.0M_30kPa, MICP0.4M_30kPa and Non-MICP_30kPa). In the case of MICP-2.0M_30kPa, the pore pressures remain stable after the initial transient stage, indicating that the MICP treated soil is not affected by the hydraulic flow. In the case of Non-MICP_30kPa, however, the pore pressure differences reduce remarkably and the pore pressures at the four locations almost converge after about 1000s, indicating that the soil's flow resistance has been damaged (Fleshman and Rice 2014; Moffat and Fannin 2011). The case of MICP-0.4M_30kPa is an intermediate situation, which displays a slight and gradual reduction in pore pressure differences. More generally, the Non-MICP and MICP samples with low treatment concentrations become heterogeneous when they reach the steady-state conditions, which are different from those of 
heterogeneous samples. Thus, different pore pressure distributions can be observed between heterogeneous and homogenous samples.

It should be noted that the pressure dissipation occurring at the top plate and double-layer bottom mesh may reduce the actual imposed hydraulic pressure across the longitudinal direction of the tested samples, especially in the cases with severe erosion.

The hydraulic conductivity is derived from the measurement of the flow rate and hydraulic pressure drop, as shown in Fig. 10. The hydraulic pressure drop between PT1 and PT4 was used for calculation to eliminate the effect of pressure dissipation by the top plate and the bottom double-layer mesh. The magnitudes of hydraulic conductivity of all tested samples before the erosion process fall into a narrow range, from $5.5 \times 10^{-5}$ to $8.0 \times 10^{-5} \mathrm{~m} / \mathrm{s}$. The increase in the cementation concentration only results in slight but limited reduction of the hydraulic conductivity. During the erosion process, all Non-MICP soils, MICP$0.2 \mathrm{M} \_30 \mathrm{kPa}$, and MICP-0.4M_30kPa experience significant increases in the hydraulic conductivity. This is attributed to the formation of erosion-induced preferential flow paths. In summary, the MICP treatment only marginally changes the permeability behaviour of the gravel-sand mixture samples, even if it substantially reduces the erosion weight and axial deformation.

It should be noted that the aerated tap water can gradually decrease the hydraulic conductivity due to the entrapment of air into the porous media (Chapuis 2004). In Fig. 10, it can be clearly seen that hydraulic conductivity decreases gradually after 500 s, especially in samples without significant erosion.

\section{Discussion}

Hydro-mechanical coupling 
During the internal erosion process, the mass loss, volumetric change and change in hydraulic conductivity normally occur simultaneously and are fully coupled. Their interactions are essential for the distinction of internal erosion modes (Fannin and Slangen 2014). The coupling relations can be also used for the comparison of erosion control efficiency by different MICP treatments. In fact, the coupling analysis method has already been used to evaluate the treatment efficiency of various erosion control methods (Indraratna et al. 2013; Jiang et al. 2016a).

Fig. 11 shows the coupling relationships between the cumulative erosion weight and volumetric change (equals to axis strain in the current study). It is clear that both Non-MICP and MICP treated samples have linear coupling relationships. Linear regression analysis reveals that MICP treated gravel-sand mixture samples attain less volumetric changes than Non-MICP samples at the same cumulative erosion weight. It is attributed to the fact that MICP creates cementations between soil particles and substantially increase the stiffness of the gravel-sand mixtures (Cheng et al. 2013; Al Qabany et al. 2012). The correlations obtained in the current study are comparable with that reported by Sibille et al. (2015). The slight difference might be due to that (1) glass beads instead of real soil particles were used in their tests and (2) the higher fine content adopted in the current study.

Fig. 12 shows the correlation between the erosion rate and flow velocity. In order to initiate erosion, the flow velocity should be large enough to dislodge and mobilise fine particles (Reddi and Bonala 1997; Richards and Reddy 2012). Therefore, the critical flow velocity is an indicator of the strength of interparticle bonds. In Fig. 12, a critical flow velocity can be clearly identified in the cases of Non-MICP, MICP-0.2M, and MICP-0.4M. More specifically, the case of Non-MICP has a critical velocity ranging from 0.00028 to $0.00037 \mathrm{~m} / \mathrm{s}$. The MICP treatment with $0.2 \mathrm{M}$ cementation does not change the critical velocity significantly $(0.00027-0.00041 \mathrm{~m} / \mathrm{s})$ while $0.4 \mathrm{M}$ cementation increases the critical 
velocity to $0.00046 \mathrm{~m} / \mathrm{s}$. For the rest three cases with higher cementation concentrations, the critical velocity cannot be determined since no erosion occurs during the test. But it is clear that their critical velocities are significantly larger than those of Non-MICP and low cementation samples. In summary, the correlations between the erosion rate and flow velocity indicate that the MICP treatment can increase critical flow velocity significantly. This is fundamentally attributed to the calcite precipitation formed by MICP, which contributes to the bonds between particles.

Based on the Kozeny-Carman equation for the permeability of porous media, the hydraulic conductivity is predominantly dependent on the void ratio of cohesionless soils as shown in Eq. (2) (Mitchell and Soga 2005):

$$
k=C D_{s}^{2}\left(\frac{\gamma_{w}}{\mu}\right) \frac{e^{3}}{1+e} S^{3}
$$

where $k$ is hydraulic conductivity, $C$ is composite pore shape factor, $D_{\mathrm{s}}$ is the characteristic grain size, $\gamma_{w}$ is the unit weight of water, $\mu$ is the water viscosity, $e$ is void ratio, and $S$ is the degree of saturation. Thus in terms of porosity, $k$ is linearly correlated to $n^{3} /(1-n)^{2}$. Although the original Kozeny-Carman equation accounts well for the dependency of permeability on void ratio (porosity) in uniformly graded sands and some silts. However, efforts were also made by other researchers to apply the Kozeny-Carman equation for the binary mixtures. For example, Koltermann and Gorelick (1995) developed a fractional packing Kozeny-Carman relation, in which the porosity term accounts for the fractional packing. This fractional packing Kozeny-Carman relation has been proved to be valid for a large range of gap-graded binary mixed soils from sand-clay to gravel-sand mixtures. The fractional packing KozenyCarman relation is also deemed to be applicable to the MICP treated gravel-sand mixtures. This is because that cementation by MICP can agglomerate particles, but does not change the granular nature of the soil. 
It should be noted that the porosity in this study was simply calculated based on the definition of porosity in classic soil mechanics (see Eq. 1). This is mathematically different from the porosity obtained from the fractional packing theory. However, the fractional packing theory aims to provide an accurate analytic method for porosity calculation for binary mixtures with different fine contents. Therefore, the value of calculated porosity from fractional packing theory is likely to be close to the measured porosity from experiments. In this sense, the actual measured porosity (Fig. 8(b)) can be approximately substituted into the fractional packing Kozeny-Carman relation for further analysis.

Fig. 13 shows the correlation between the hydraulic conductivity and $n^{3} /(1-n)^{2}$ of both Non-MICP and MICP-treated gravel-sand mixture samples under the imposed hydraulic pressure of $30 \mathrm{kPa}$. Linear relations can be found between the hydraulic conductivity and $n^{3} /(1-n)^{2}$. In particular, the slope values of fitted straight lines are quite similar in the cases of Non-MICP_30kPa and MICP-0.2M_30kPa, but are significantly smaller than that of MICP treated samples with higher cementation concentrations. Based on Eq. 2, a greater slope value of the fitted straight line corresponds to a larger product of composite pore shape factor and characteristic grain size. It then can be inferred that the MICP treatment with higher cementation concentration results in the enlargement of soil particles and the change of pore shapes, which are due to the formation of more calcite precipitation as cementitious bonds. It should be noted that in the cases of Non-MICP-30kPa and MICP-0.2M_30kPa, the linear correlations between $k$ and $n^{3} /(1-n)^{2}$ are only valid when the preferential paths have not yet formed throughout the samples. For the points circled by the dotted lines, substantial erosion has already occurred, leading to the formation of preferential paths throughout the longitudinal direction of the samples. Therefore, they are not accounted for the linear correlation. This may indicate that the Kozeny-Carman equation is only valid for homogeneous binary mixtures. 
The above hydro-mechanical coupling analysis illustrates that the Non-MICP and MICP treated samples have different internal erosion modes. For the Non-MICP samples, sand loss accompanies soil compaction and permeability increase, which show evidence of suffusion, suffosion and piping at different stages of the erosion tests (Moffat et al. 2011; Fanin and Slangen 2014). For the MICP treated soils with high cementation concentrations ( $\geq 0.6 \mathrm{M})$, sand loss (although very few) accompanies no volumetric change and marginal change in permeability. This matches the mode of suffusion (Fannin and Slangen 2014). The MICP treated soils with low cementation concentrations $(\leq 0.4 \mathrm{M})$ are in an intermediate state.

\section{Calcite precipitation}

Fig. 14 illustrates the distribution of calcite precipitation content in the MICP treated samples. It is apparent that the average precipitation content increases steadily with the increase of cementation concentration. In addition, it is found that the distribution of calcite precipitation in the soils is not quite uniform. Typically, the highest local precipitation content is found at the lower middle part of the samples. The second highest precipitation content is at the upper-middle part while the top and bottom have the least precipitation. In the case of MICP-2.0M, the highest precipitation content is found at the bottom. Since the precipitation, nucleation and crystal growth rates of calcium carbonate are highest in the case of MICP-2.0M, which is due to the highest supersaturation of calcium ions, local clogging is most likely to occur around the bacteria percolation point (bottom of the gravel-sand samples) immediate after the mixing of bacteria and cementation solution in this case, as shown in Fig. 14. On the other hand, when the cementation concentration is low (i.e., $0.2 \mathrm{M}$ to $1.0 \mathrm{M}$ ), the rate of calcite formation is slower and the zone around injection point is less likely to be clogged, resulting in a more uniform distribution of calcite precipitation within the soil, as 
shown in Fig. 14. Further study is needed to improve the uniformity of calcite precipitation in the gravel-sand mixtures using this particular MICP implementation method.

The calcite precipitation content is regarded as the predominant controlling factor for the improvement of mechanical and hydraulic properties of soils (Cheng et al. 2014; Feng and Montoya 2016; Lin et al. 2016; Al Qabany and Soga 2013). In this study, the overall calcite precipitation content was correlated with the total erosion weight, as shown in Fig. 15. More calcite precipitation corresponds to less erosion weight regardless of the imposed hydraulic pressure. In particular, at least $0.28 \%$ calcite precipitation is needed in order to keep erosion percentage lower than $1 \%$. As suggested by Vallejo (2001), the gravel-sand mixture containing $50 \%$ sand possesses a transitional fine grain supported structure. The presence of calcite precipitation thus is presumed to primarily contribute to the particle-to-particle cementation between sand particles. The higher the precipitation content is, the larger size of clusters of cemented sand particles can be obtained. When the size of clusters of sand particles is larger than the pore throat size in the gravel-sand mixture, sand particles are prevented to be flushed out. More microstructural observations are needed to confirm this hypothesis.

\section{Conclusions}

This paper reports an investigation of the MICP technique for internal erosion control in gravel-sand mixtures. Soil mixture samples treated with cementation solutions of varied concentrations are subject to the constant-pressure internal erosion tests. The following conclusions are obtained from this study:

(1) MICP treatment contributes to the reduction in the cumulative erosion weight, erosion rate and axial strain relative to the Non-MICP soil. A cementation concentration higher than $0.4 \mathrm{M}$ can bring down the erosion and axial deformation to the negligible 
level. The magnitudes of hydraulic conductivity for all tested samples before the erosion process fall into a narrow range, from $5.5 \times 10^{-5}$ to $8.0 \times 10^{-5} \mathrm{~m} / \mathrm{s}$. The increase in cementation concentration only results in slight but limited reduction in the hydraulic conductivity. After the erosion process, the Non-MICP soils and MICP treated soils with low cementation concentrations under a high hydraulic pressure experience significant increases in the hydraulic conductivity.

(2) The Non-MICP and MICP treated samples have linear relationships between the cumulative erosion weight and volumetric change percentage. The MICP treated gravel-sand mixture samples attain less volumetric changes than the Non-MICP samples at the same cumulative erosion weight. Erosion rate-flow rate correlations reveal that the MICP treatment contributes to an enhanced critical flow rate relative to the Non-MICP samples. Linear relationship is also found between hydraulic conductivity and $n^{3} /(1-n)^{2}$. The hydro-mechanical analysis demonstrates the erosion mode of suffusion for the cementation concentration $\geq 0.6 \mathrm{M}$ and a combination of suffosion, suffusion and piping for the cementation concentration $\leq 0.4 \mathrm{M}$.

(3) The average calcium carbonate precipitation content increases steadily with the increasing cementation concentration, though the precipitation distribution is nonuniform within the soils. More calcite precipitation corresponds to less erosion weight regardless of the imposed hydraulic pressure. The formation of clusters of cemented sand particles is fundamentally responsible for the reduction in soil erosion.

Further studies are planned to examine the erosional and hydromechanical behaviours of the MICP treated gravel-sand mixtures with various gradings and fine contents and under different axis stresses and hydraulic pressures. The effect of different MICP implementation strategies (e.g., premixing and injection methods) on the improvement of erosion-resistance will also be investigated accordingly. 


\section{Acknowledgements}

The authors thank Mr. Knight Chris for production of the experimental device and thank Miss Bo Li and Dr. Linfeng Guo for the commissioning of the electronic system. Special thanks are also extended to Dr. Matthew Kuo, Mr. Osama Dawoud and Dr. Fei Jin for their involvements in device results analysis and discussion. The first author also extends thanks to the Cambridge Commonwealth, European \& International Trust for the financial support in the PhD studentship.

\section{References}

Al Qabany, A. \& Soga, K. (2013). Effect of chemical treatment used in MICP on engineering properties of cemented soils. Géotechnique 63, No. 4, 331-339.

Al Qabany, A., Soga, K. \& Santamarina, C. (2012). Factors affecting efficiency of microbially induced calcite precipitation. J. Geotech. Geoenviron. Engng. 138, No. 8, $992-1001$.

Bendahmane, F., Marot, D. \& Alexis, A. (2008). Experimental parametric study of suffusion and backward erosion. J. Geotech. Geoenviron. Engng. 134, No. 1, 57-67.

Centers for Disease Control and Prevention (CDCP). (2009). Biosafety in Microbiological and Biomedical Laboratories, 5th edition. Washington D.C., USA: U.S. Department of Health and Human Services.

Chang, D. \& Zhang, L. (2013a). Critical hydraulic gradients of internal erosion under complex stress states. J. Geotech. Geoenviron. Engng. 139, No. 9, 1454-1467.

Chang, D. \& Zhang, L. (2013b). Extended internal stability criteria for soils under seepage. Soils Found. 53, No. 4, 569-583. 
Chapuis, R. P. (2004). Permeability tests in rigid-wall permeameters: determining the degree of saturation, its evolution, and its influence on test results. Geotech. Test. J. 27, No. 3, 304-313.

Cheng, L., Cord-Ruwisch, R. \& Shahin, M. A. (2013). Cementation of sand soil by microbially induced calcite precipitation at various degrees of saturation. Can. Geotech. J. 50, No. 1, 81-90.

Cheng, L., Shanin, M. A. \& Cord-Ruwisch, R. (2014). Bio-cementation of sandy soil using microbially induced carbonate precipitation for marine environments. Géotechnique 64, No. $12,1010-1013$.

Chu, J., Ivanov, V., Stabnikov, V. \& Li, B. (2013). Microbial method for construction of aquaculture pond in sand. Géotechnique 63, No. 10, 871-875.

Correia dos Santos, R., Caldeira, L. \& Maranha das Neves, E. (2015). Experimental study on crack filling by upstream fills in dams. Géotechnique 65, No. 3, 218-230.

Danka, J. \& Zhang, L. M. (2015). Dike failure mechanisms and breaching parameters. J. Geotech. Geoenviron. Engng. 141, No. 9, 04015039.

Dawoud, O., Chen, C. Y. \& Soga, K. (2014). Microbial induced calcite precipitation for geotechnical and environmental applications. Proceedings of 2014 GeoShanghai International Congress: New Frontiers in GeoTechnical Engineering, Shanghai, 11-18. Reston, USA: American Society of Civil Engineers.

DeJong, J. T., Mortensen, B. M., Martinez, B. C. \& Nelson, D. C. (2010). Bio-mediated soil improvement. Ecol. Engng. 36, No. 2, 197-210.

DeJong, J. T., Martinez, B. C., Ginn, T. R., Hunt, C., Major, D. \& Tanyu, B. (2014). Development of scaled repeated five-spot treatment model for examining microbial induced calcite precipitation feasibility in field applications. Geotech. Test. J. 37, No. 3, $1-12$. 
De Muynck, W., De Belie, N. \& Verstraete, W. (2010). Microbial carbonate precipitation in construction materials: A review. Ecol. Eng. 36, No. 2, 118-136.

Fannin, R. J. \& Slangen, P. (2014). On the distinct phenomena of suffusion and suffosion. Géotechnique Lett. 4, 289-294.

Fell, R., MacGregor, P., Stapledon, D. \& Bell, G. (2005). "Control of seepage, internal erosion and piping for embankment dams." Geotechnical Engineering of Dams, Chapter 10, 393-439. London, UK: Taylor \& Francis Group plc.

Feng, K. \& Montoya, B. M. (2016). Influence of confinement and cementation level on the behavior of microbial-induced calcite precipitated sands under monotonic drained loading. J. Geotech. Geoenviron. Engng.142, No. 1, 04015057.

Ferris, F., Phoenix, V., Fujita, Y. \& Smith, R. (2004). Kinetics of calcite precipitation induced by ureolytic bacteria at 10 to $20 \mathrm{C}$ in artificial groundwater. Geochim. Cosmochim. Ac. 67, No. 8, 1701-1710.

Fidaleo, M \& Lavecchia, R. (2003). Kinetic study of enzymatic urea hydrolysis in the pH range 4-9. Chem. Biochem. Eng. Q. 17, No. 4, 311-318.

Fleshman, M. \& Rice, J. (2014). Laboratory modeling of the mechanisms of piping erosion initiation. J. Geotech. Geoenviron. Engng. 140, No. 6, 04014017.

Foster, M., Fell, R. \& Spannagle, M. (2000). The statistics of embankment dam failures and accidents. Can. Geotech. J. 37, No. 5, 1000-102.

Hammes, F. \& Verstraete, W. (2002). Key roles of pH and calcium metabolism in microbial carbonate precipitation. Rev. Environ. Sci. Biotech. 1, 3-7.

Indraratna, B., Athukorala, R. \& Vinod, J. (2013). Estimating the rate of erosion of a silty sand treated with lignosulfonate. J. Geotech. Geoenviron. Engng. 139, No. 5, 701-714. 
Indraratna, B., Israr, J. \& Rujikiatkamjorn, C. (2015). Geometrical method for evaluating the internal instability of granular filters based on constriction size distribution. J. Geotech. Geoenviron. Engng. 141, No. 10, 04015045.

Indraratna, B., Muttuvel, T., Khabbaz, H. \& Armstrong, R. (2008). Predicting the erosion rate of chemically treated soil using a process simulation apparatus for internal crack erosion. J. Geotech. Geoenviron. Engng.134, No. 6, 837-844.

Jiang, N. J., Soga, K. \& Kuo, M. (2016a). Microbially induced carbonate precipitation (MICP) for seepage-induced internal erosion control in sand-clay mixtures. J. Geotech. Geoenviron. Engng. doi: 10.1061/(ASCE)GT.1943-5606.0001559.

Jiang, N. J., Yoshioka, H., Yamamoto, K. \& Soga, K. (2016b). Ureolytic activities of a urease-producing bacterium and purified urease enzyme under the anoxic condition: Implication for subseafloor sand production control by microbially induced calcite precipitation (MICP). Ecol. Engng. 90, 96-104.

Ke, L. \& Takahashi, A. (2014). Triaxial erosion test for evaluation of mechanical consequences of internal erosion. Geotech. Test. J. 37, No. 2, 347-364.

Ke, L. \& Takahashi, A. (2015). Drained monotonic responses of suffusional cohesionless soils. J. Geotech. Geoenviron. Engng. 141, No. 8, 04015033

Kenney, T. C. \& Lau, D. (1986). Internal stability of granular filters: Reply. Can. Geotech. J. 23, No. 3, 420-423.

Kézdi, Á. (1979). Soil physics: selected topics. Developments in geotechnical engineering. Amsterdam, The Netherlands: Elsevier Scientific Pub. Co..

Koltermann, C. E. \& Gorelick, S. M. (1995). Fractional packing model for hydraulic conductivity derived from sediment mixtures. Water. Resour. Res. 31, No. 12, 3283-3297.

Lafleur, J., Mlynarek, J. \& Rollin, A. (1989). Filtration of broadly graded cohesionless soils. J. Geotech. Enging. 115, No. 12, 1747-1768. 
Lauchnor, E. G., Topp, D. M., Parker, A. E. and Gerlach, R. (2015). Whole cell kinetics of ureolysis by Sporosarcina pasteurii. J. Appl. Microbial. 118, No. 6, 1321-1332.

Li, M. \& Fannin, R. J. (2008). Comparison of two criteria for internal stability of granular soil. Can. Geotech. J. 45, No. 9, 1303-1309.

Lin, H., Suleiman, M. T., Brown, D. G. \& Kavazanjian, E. (2016). Mechanical behavior of sands treated by microbially induced carbonate precipitation. J. Geotech. Geoenviron. Engng. 142, No. 2, 04015066.

Martinez, B., DeJong, J. T., Ginn, T., Montoya, B., Barkouki, T., Hunt, C., Tanyu, B. \& Major, D. (2013). Experimental optimization of microbial-induced carbonate precipitation for soil improvement. J. Geotech. Geoenviron. Engng. 139, No. 4, 587-598.

Milligan, V. (2003). Some uncertainties in embankment dam engineering. J. Geotech. Geoenviron. Engng. 129, No. 9, 785-797.

Mitchell, J. K. \& Soga, K. (2005). Fundamentals of Soil Behavior, Third Edition. New York, USA: John Wiley and Sons, Inc..

Moffat, R. \& Fannin, R. J. (2011). A hydromechanical relation governing internal stability of cohesionless soil. Can. Geotech. J. 48, No. 3, 413-424.

Moffat, R., Fannin, R. J. \& Garner, S. J. (2011). Spatial and temporal progression of internal erosion in cohesionless soil. Can. Geotech. J. 48, No. 3, 399-412.

Montoya, B., DeJong, J. T. \& Boulanger, R. (2013). Dynamic response of liquefiable sand improved by microbial-induced calcite precipitation. Géotechnique 63, No. 4, 302-312.

Ouyang, M. \& Takahashi, A. (2015). Optical quantification of suffosion in plane strain physical models. Géotechnique Lett. 5, 118-122.

Ouyang, M. \& Takahashi, A. (2016). Influence of initial fines content on fabric of soils subjected to internal erosion. Can. Geotech. J. 53, No. 2, 299-313. 
Planès, T., Mooney, M. A., Rittgers, J. B. R., Parekh, M. L., Behm, M. \& Snieder, R. (2016). Time-lapse monitoring of internal erosion in earthen dams and levees using ambient seismic noise. Géotechnique 66, No. 4, 301-312.

Reddi, L. \& Bonala, M. (1997). Critical shear stress and its relationship with cohesion for sand. kaolinite mixtures. Can. Geotech. J. 34, No. 1, 26-33.

Reddi, L., Lee, I. \& Bonala, M. (2000). Comparison of internal and surface erosion using flow pump tests on a sand-kaolinite mixture. Geotech. Test. J. 23, No. 1, 116-122.

Richards, K. S. \& Reddy, K. R. (2012). Experimental investigation of initiation of backward erosion piping in soils. Géotechnique, 62, No. 10, 933-942.

Seagren, E. \& Aydilek, A. (2010). "Biomediated geomechanical processes." Environmental Biology, 319-349. Hoboken, USA: John Wiley and Sons, Inc..

Sibille, L., Marot, D. \& Sail, Y. (2015). A description of internal erosion by suffusion and induced settlements on cohesionless granular matter. Acta Geotech. 10, No. 6, 735-748.

U.S. Bureau of Reclamation (USBR). (1999). Protective filters. Design Standards No. 13 Embankment dams, Chapter 5. Denver, USA: U.S. Department of Interior, Bureau of Reclamation.

Vallejo, L. E. (2001). Interpretation of the limits in shear strength in binary granular mixtures. Can. Geotech. J. 38, No. 5, 1097-1104.

Whiffin, V. S. (2004). Microbial $\mathrm{CaCO}_{3}$ precipitation for the production of biocement. Perth, Australia: Murdoch University.

Whiffin, V. S., van Paassen, L. A. \& Harkes, M. P. (2007). Microbial carbonate precipitation as a soil improvement technique. Geomicrobiol. J. 24, No. 5, 417-423. 


\section{List of table captions}

Table. 1 Biological and cementation media.

Table 2 Specifications for internal erosion test. 
Table 1 Biological and cementation media

Biological media

Solid $\mathrm{NH}_{4}-\mathrm{YE}$

Yeast extract

Ammonium sulphate

$20 \mathrm{~g} / \mathrm{L}$

Agar

$10 \mathrm{~g} / \mathrm{L}$

Tris buffer

$20 \mathrm{~g} / \mathrm{L}$

$0.13 \mathrm{M}$

Rehydrate the bacterium strain in petri dishes

Urea-rich $\mathrm{NH}_{4}$-YE

Yeast extract

Ammonium sulphate

$20 \mathrm{~g} / \mathrm{L}$

Urea

$10 \mathrm{~g} / \mathrm{L}$

$0.5 \mathrm{M}$

Injected as the saturation

Tris buffer

$0.13 \mathrm{M}$ procedure for tested soils

S. pasteurii

$\mathrm{OD}_{600}=0.454 \pm 0.137$;

Specific urea activity $=$ $1.012 \pm 0.390 \mathrm{mM}$ urea $\cdot \mathrm{min}^{-1} \cdot \mathrm{OD}^{-1}$

Cementation solution

Urea $^{1}$

$0.2 \mathrm{M}, 0.4 \mathrm{M}, 0.6 \mathrm{M}, 1.0 \mathrm{M}, 2.0 \mathrm{M}$

Blended with dry gravel-

Calcium chloride ${ }^{1}$

$0.2 \mathrm{M}, 0.4 \mathrm{M}, 0.6 \mathrm{M}, 1.0 \mathrm{M}, 2.0 \mathrm{M}$

Nutrient broth $6 \mathrm{~g} / \mathrm{L}$ sand mixture to achieve $w_{\text {op }}$ before compaction

${ }^{1}$ The concentration ratio between urea and calcium chloride is unity in all cementation solutions. 
Table 2 Specifications for internal erosion test

Total testing

Sand collection time $(\mathrm{kPa})$ $(\mathrm{kPa})$ time (min) (min)

\begin{tabular}{|c|c|c|c|c|}
\hline Non-MICP ${ }^{1}$ & & $15,20,30$ & & \\
\hline MICP-0.2M ${ }^{2}$ & & $15,20,30$ & & \\
\hline MICP-0.4M ${ }^{3}$ & 24 & $15,20,30$ & 30 & $0,0.5,1,2,3,5,7$ \\
\hline MICP-0.6M ${ }^{4}$ & 24 & 30 & & $10,13,16,20,30$ \\
\hline MICP-1.0M ${ }^{5}$ & & 30 & & \\
\hline MICP-2.0M ${ }^{6}$ & & 30,50 & & \\
\hline
\end{tabular}

${ }^{1}$ Samples without MICP treatment

${ }^{2}$ Samples with MICP treatment using $0.2 \mathrm{M}$ cementation solution

${ }^{3}$ Samples with MICP treatment using $0.4 \mathrm{M}$ cementation solution

${ }^{4}$ Samples with MICP treatment using 0.6 M cementation solution

${ }^{5}$ Samples with MICP treatment using $1.0 \mathrm{M}$ cementation solution

${ }^{6}$ Samples with MICP treatment 


\section{List of figure captions}

Fig. 1 The overall schematic of the meso-scale internal erosion simulator with MICP implementation unit

Fig. 2 Details of key components of the internal erosion test apparatus ((a). pedestal; (b). double-layer bottom mesh; (c) porous loading piston; (d) sealing between piston rod and top plate)

Fig. 3 Particle size distribution curves for the gravel, sand and their binary mixture used in this study

Fig. 4 Schematic of sample preparation and MICP implementation procedures

Fig. 5 Photos of sand-gravel mixtures after internal erosion test ((a). Non-MICP_15kPa; (b). Non-MICP_20kPa; (c). Non-MICP_30kPa; (d). MICP-0.2M_15kPa; (e). MICP-0.2M_20kPa; (f). MICP-0.2M_30kPa; (g). MICP-0.4M_15kPa; (h). MICP-0.4M_20kPa; (i). MICP0.4M_30kPa; (j). MICP-0.6M_30kPa; (k). MICP-1.0M_30kPa; (1). MICP-2.0M_30kPa; (m). MICP-2.0M_50kPa)

Fig. 6 Evolutions of cumulative erosion weight and erosion rate with time

Fig. 7 Remaining sand contents in soils after internal erosion test

Fig. 8 Axial displacement and overall porosity of samples subject to internal erosion test

Fig. 9 changes in pore pressure at different locations within gravel-sand mixture samples (The distance is measured from the bottom of soil samples)

Fig. 10 Changes in hydraulic conductivity with time

Fig. 11 Correlations between volumetric change and cumulative erosion weight

Fig. 12 Correlations between erosion rate and flow velocity (red circles mark the points due to formation of preferential paths) 
Fig. 13 Correlations between hydraulic conductivity and porosity (red circles mark the points due to formation of preferential paths)

Fig. 14 Distribution of calcium carbonate precipitation content within MICP treated samples

Fig. 15 Correlation between total erosion weight and carbonate precipitation content 


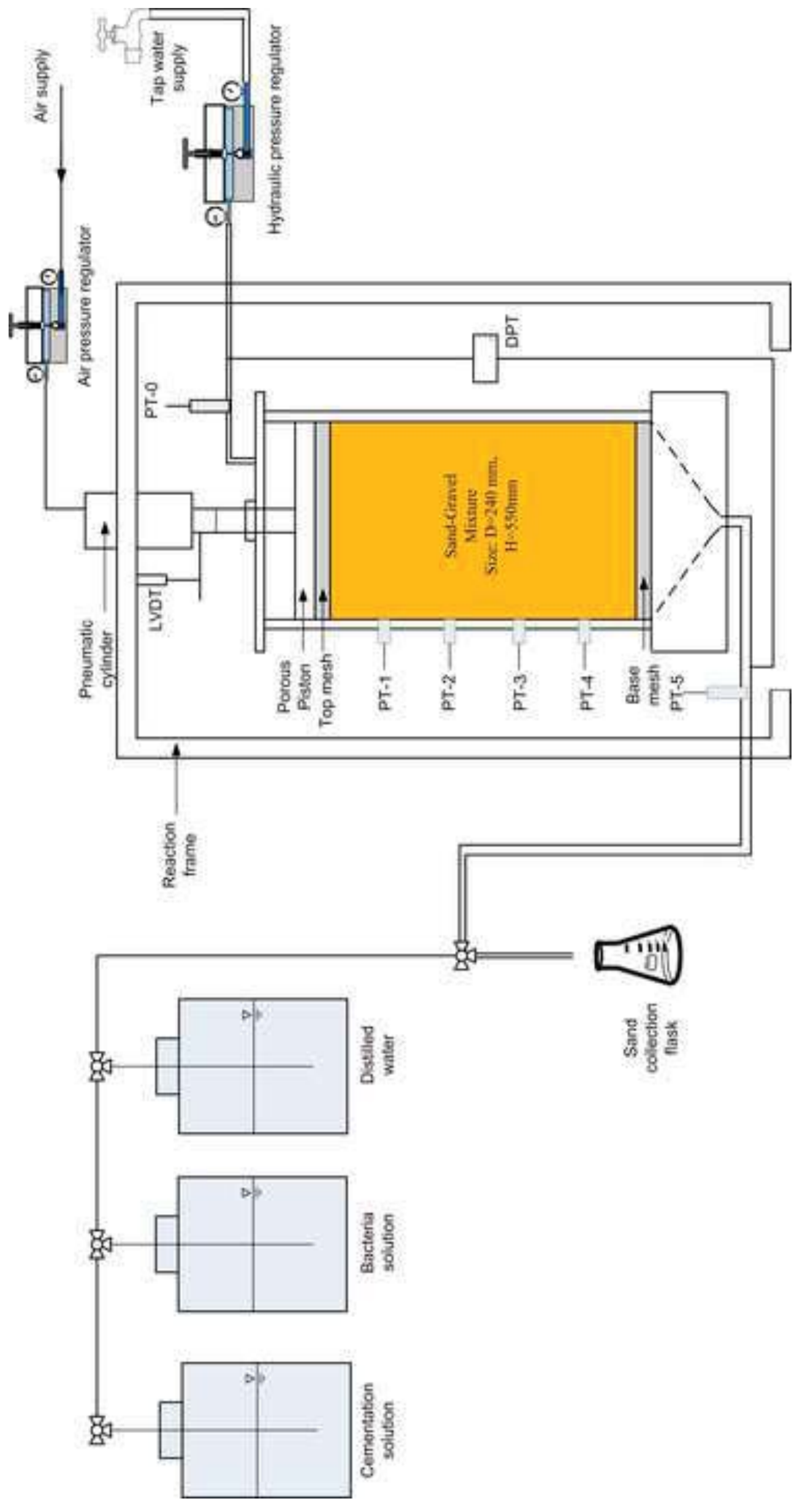



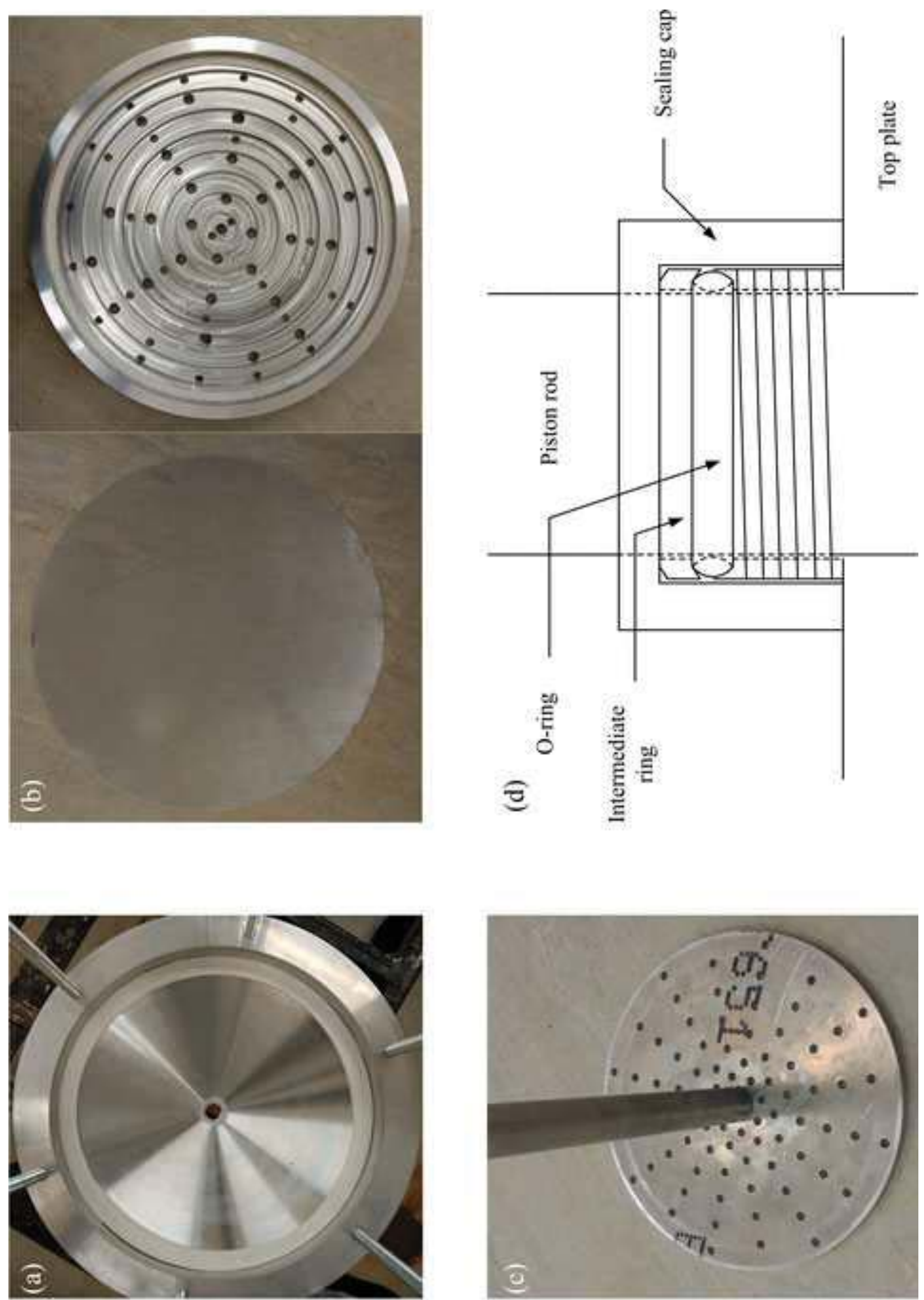

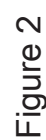




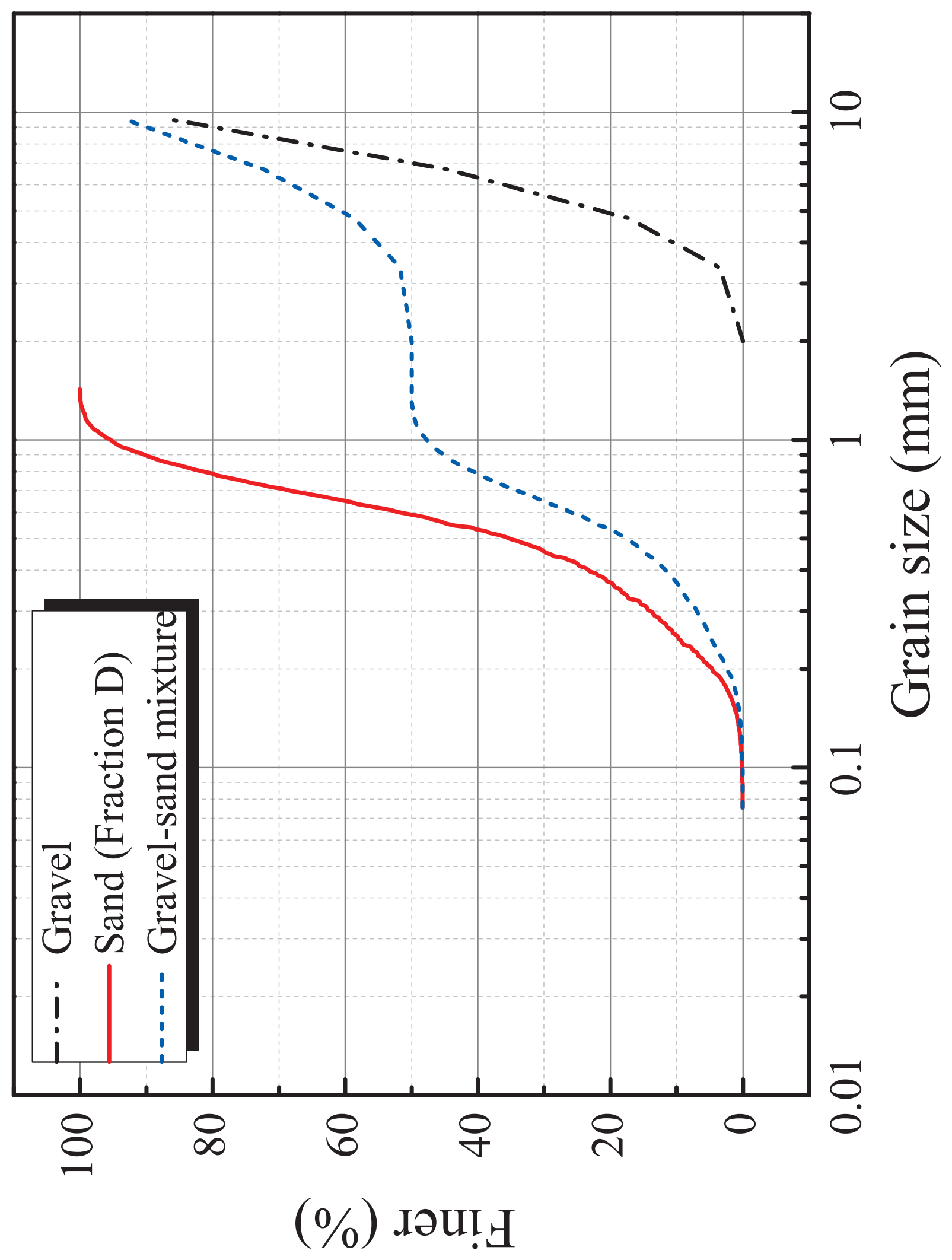




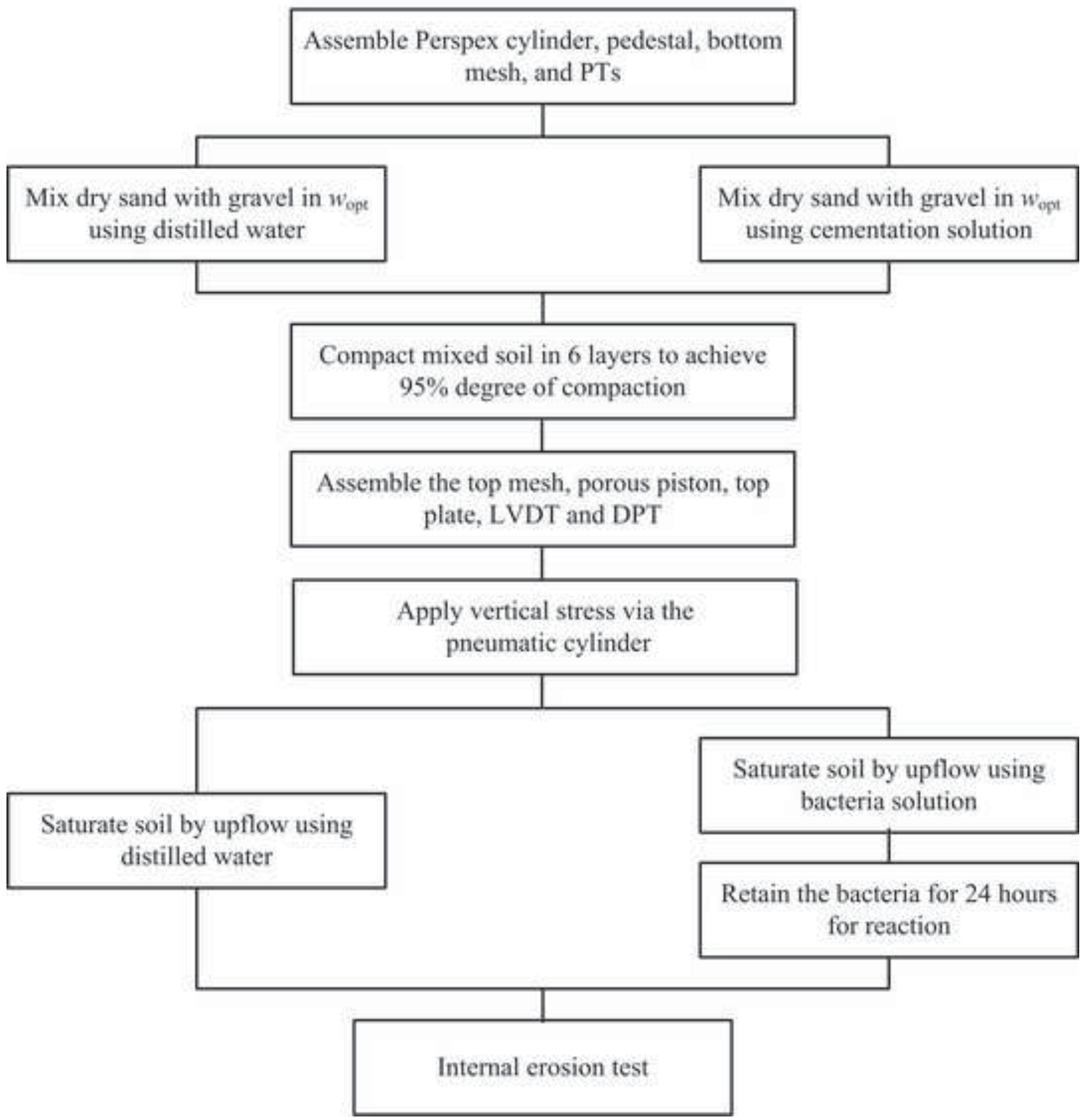




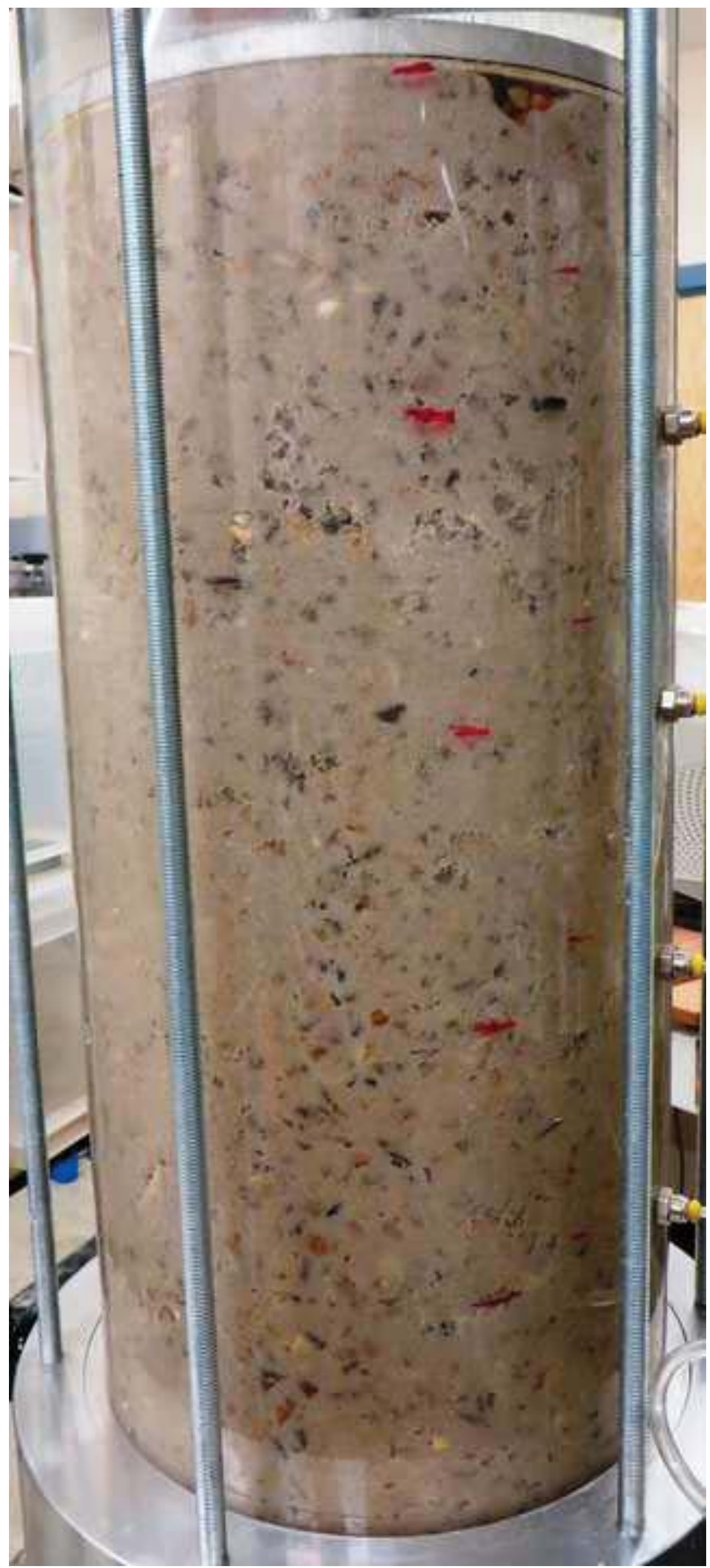




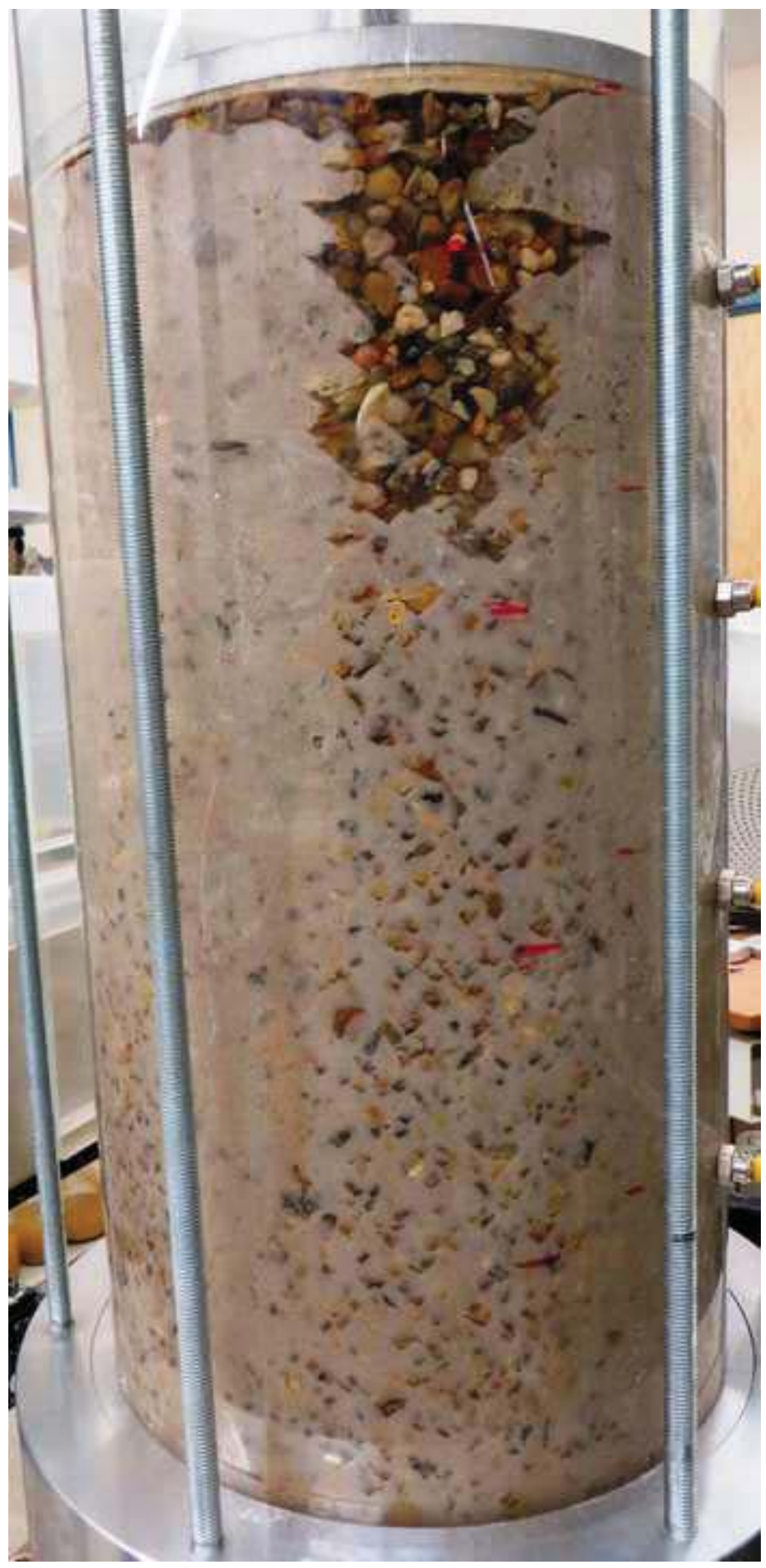




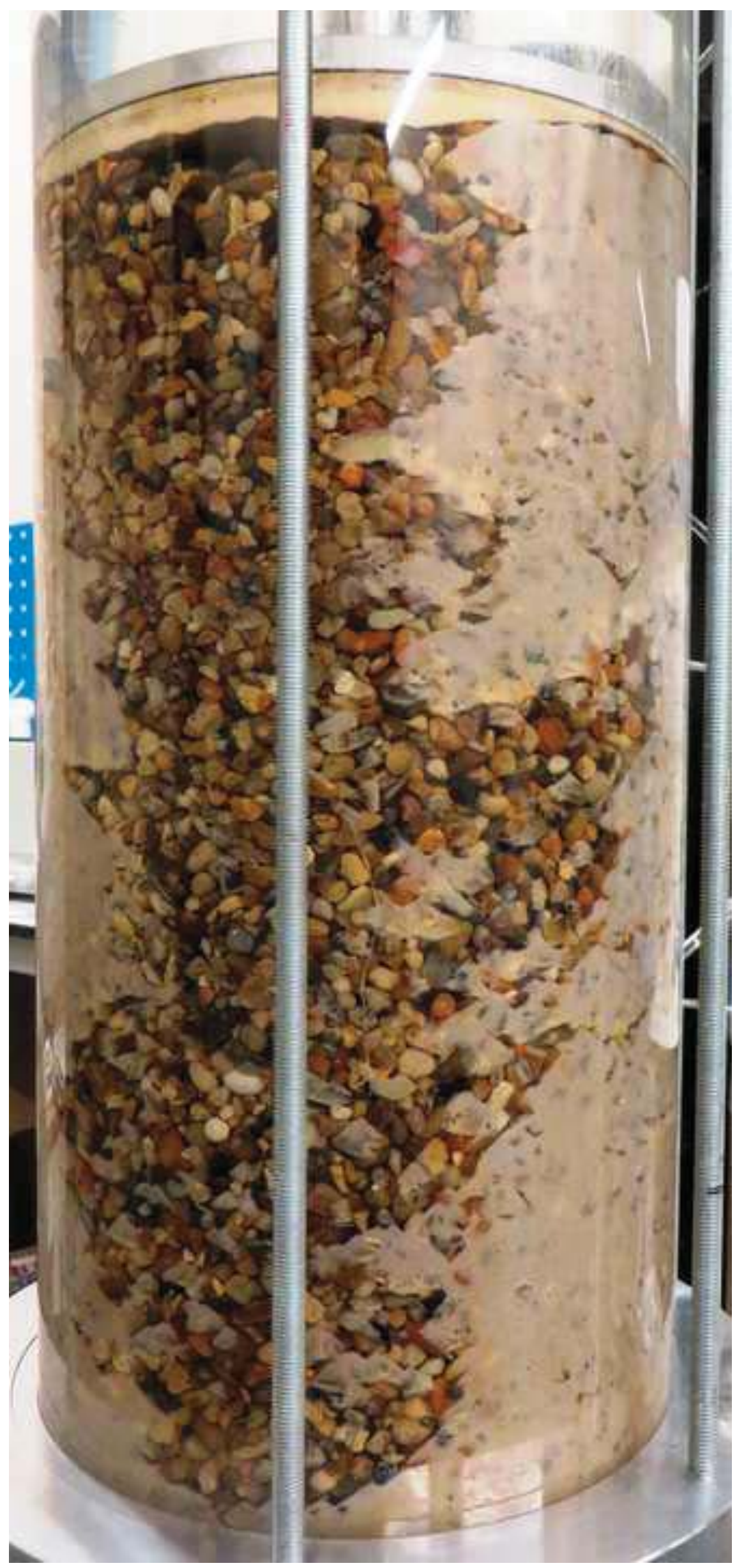




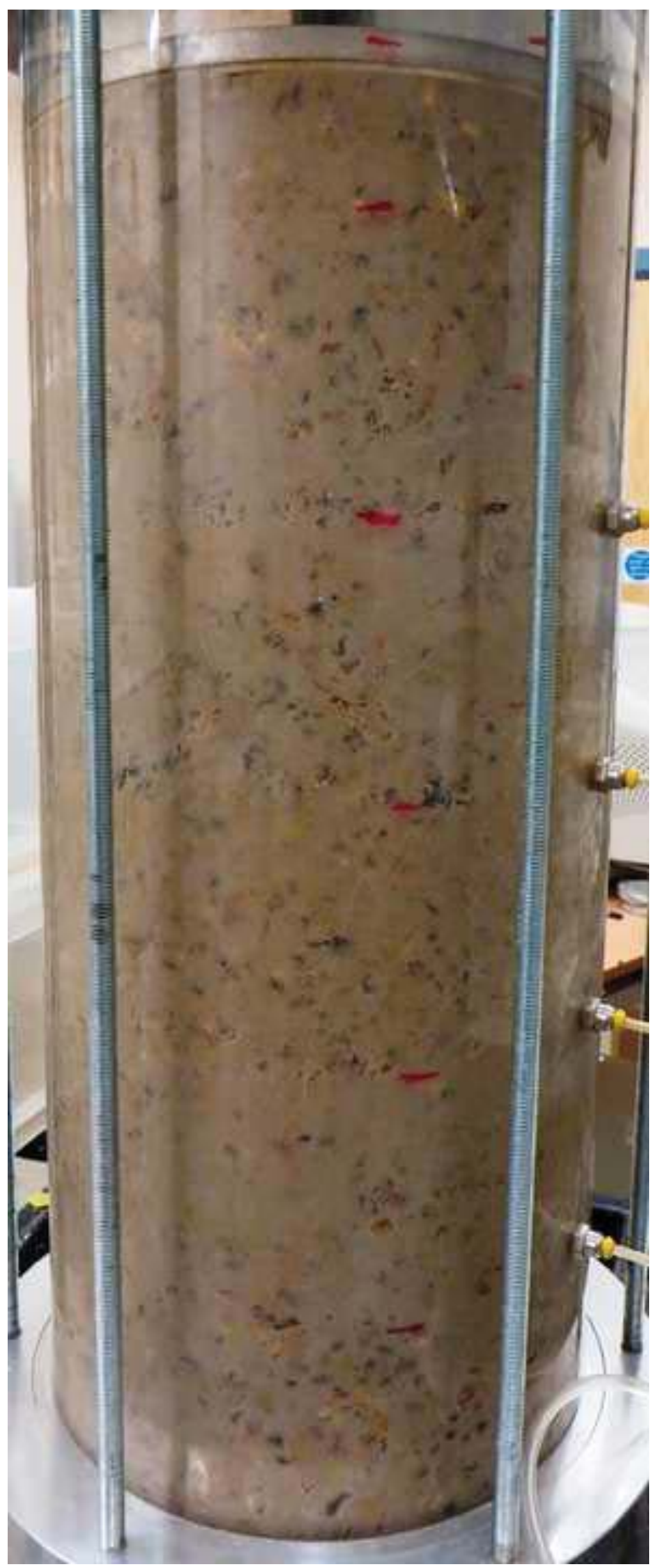




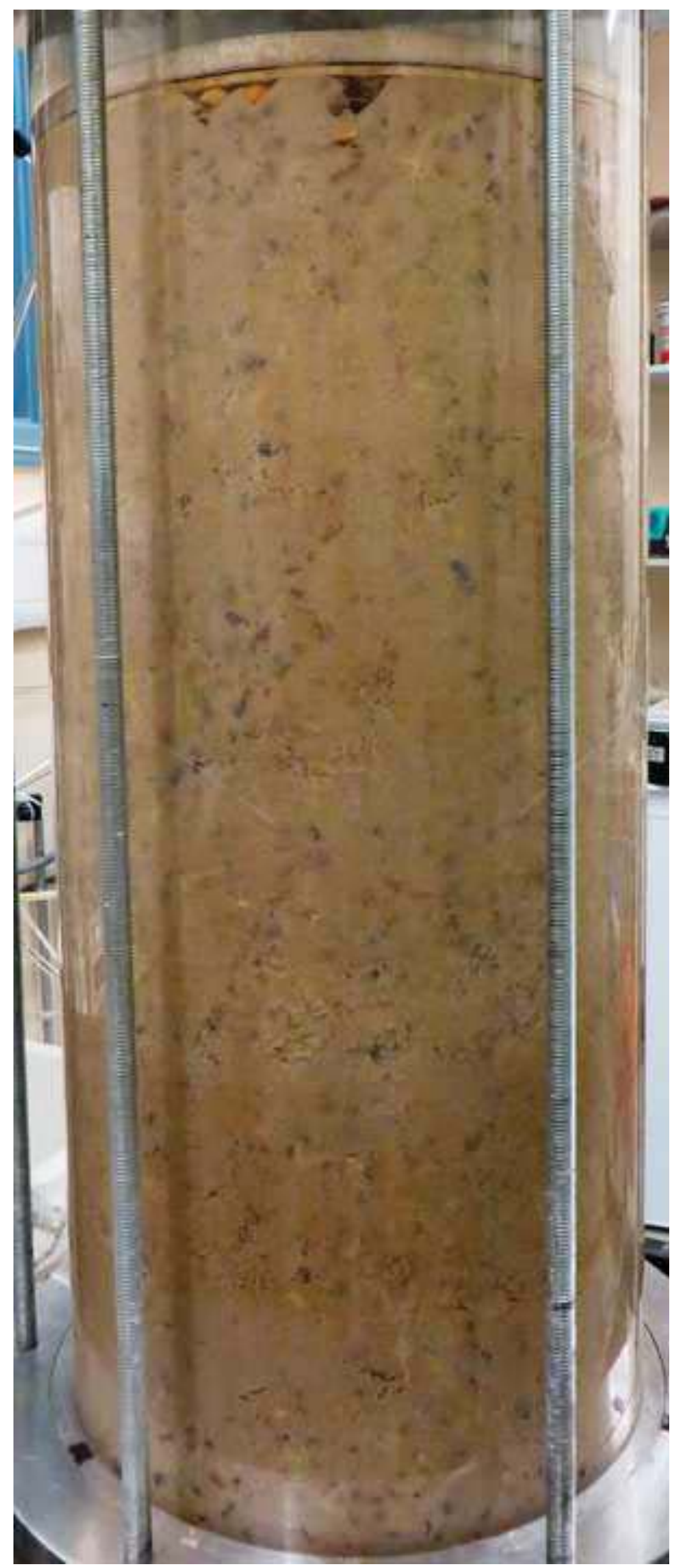




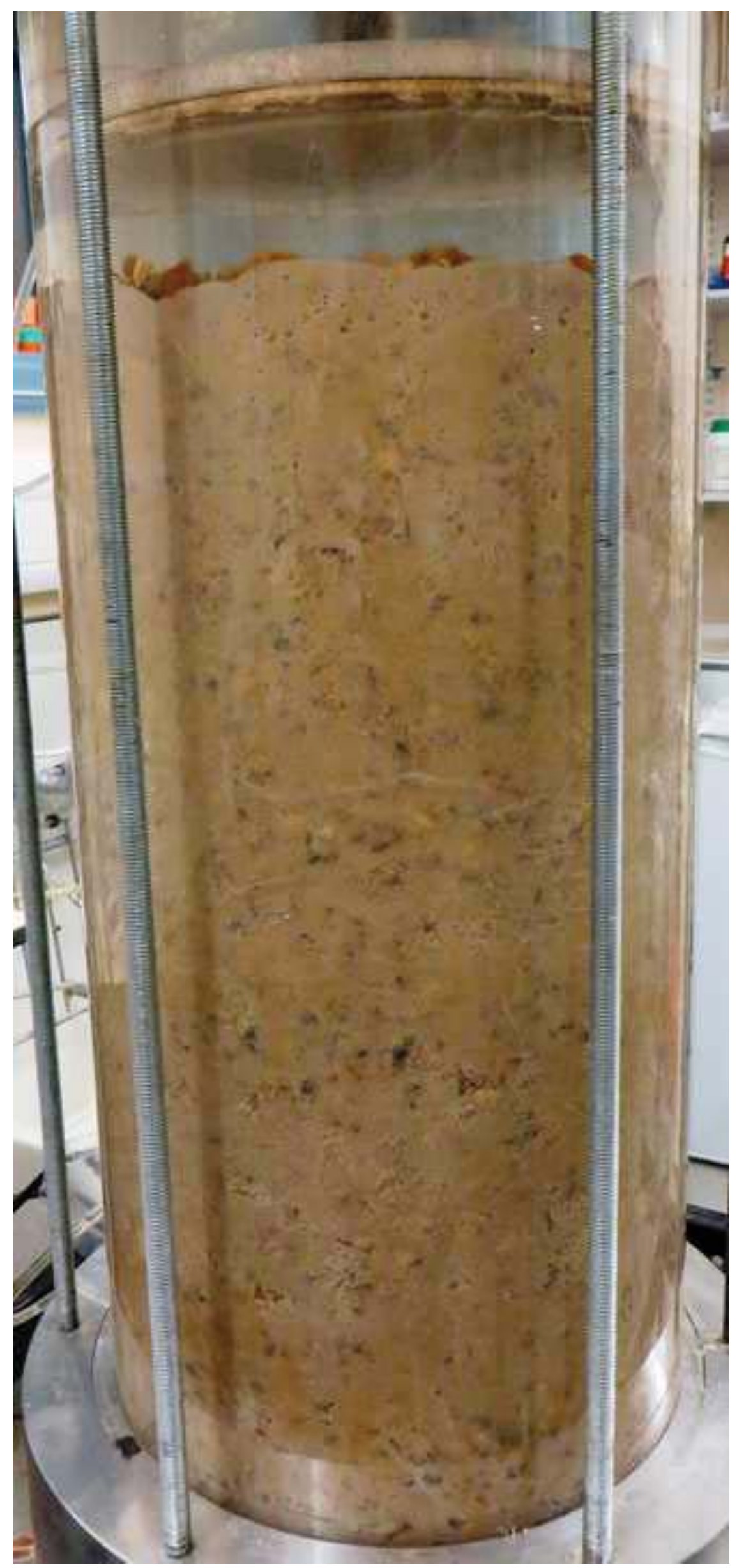




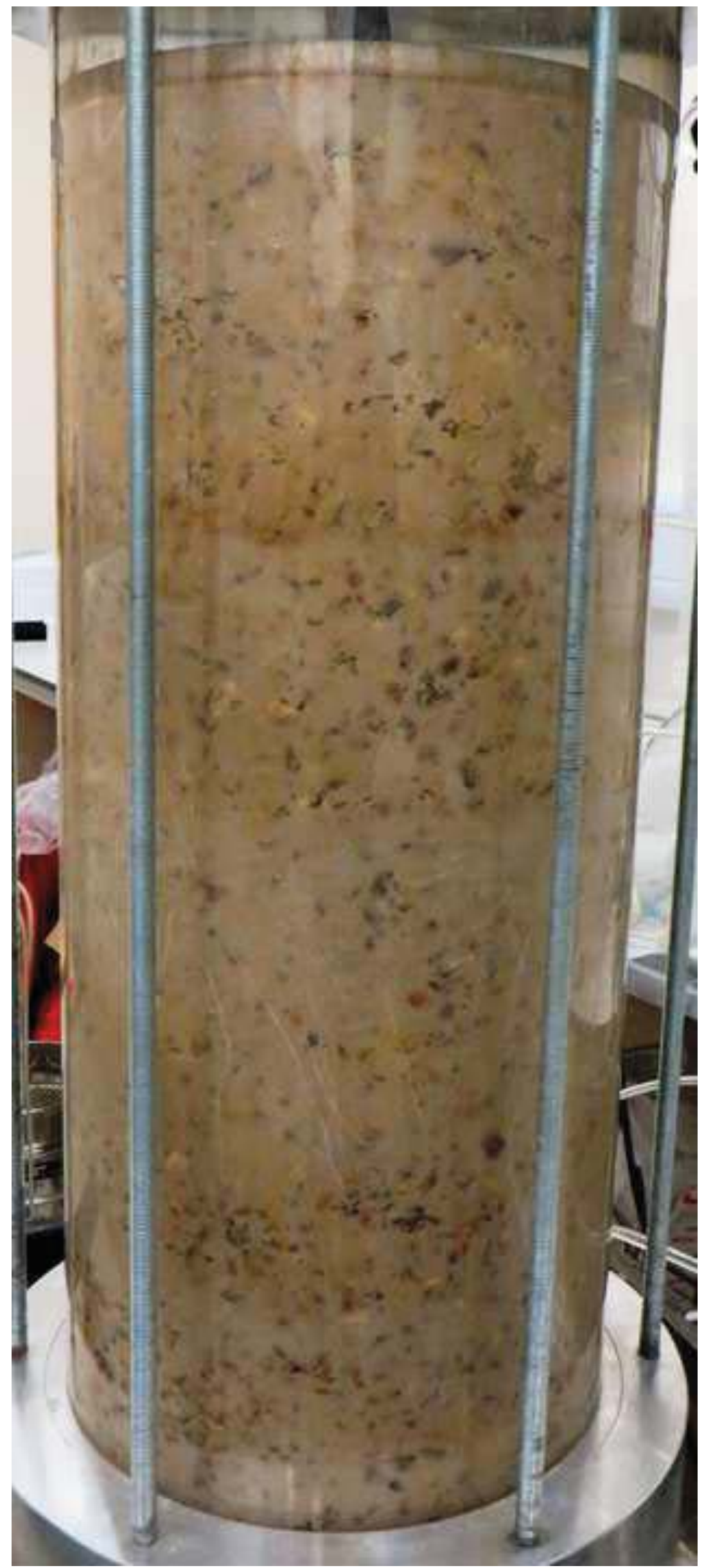




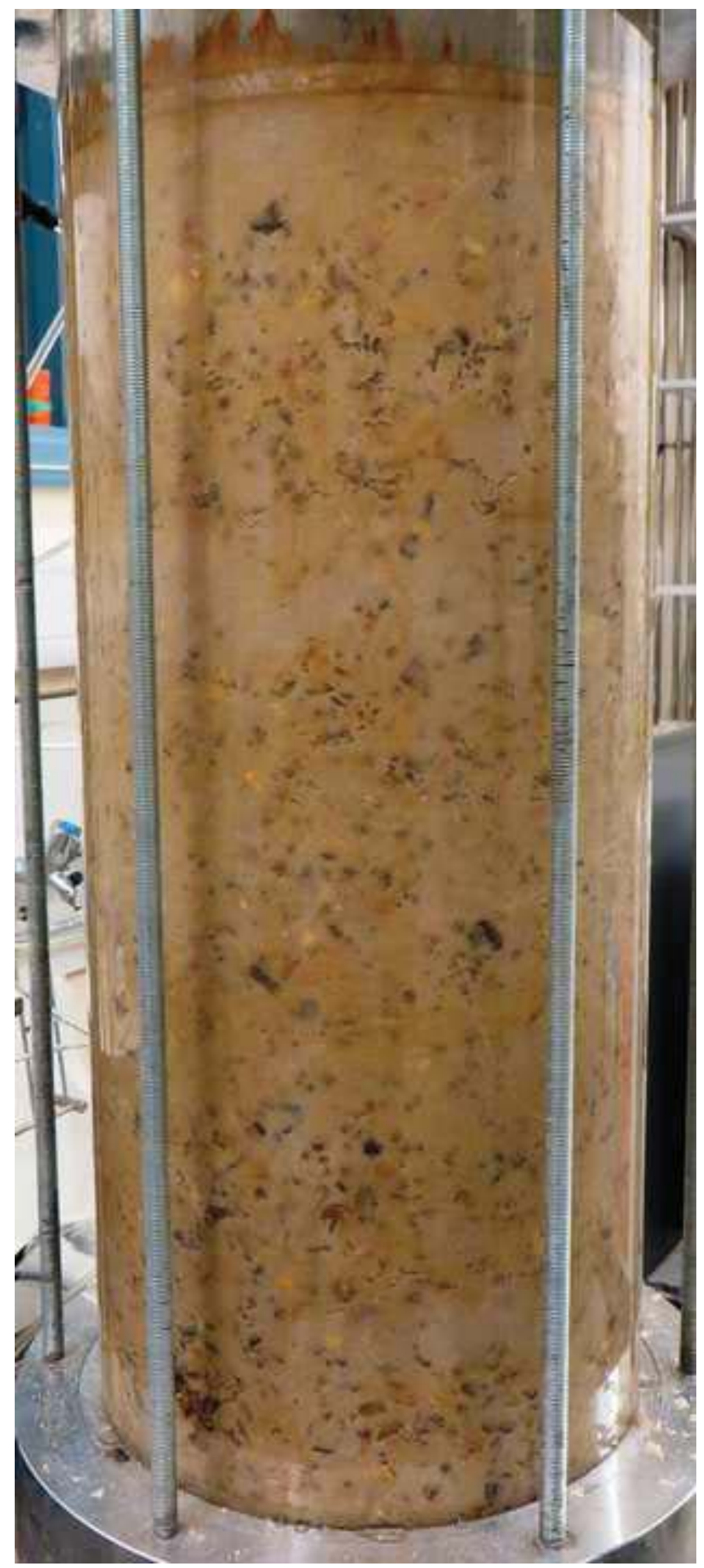




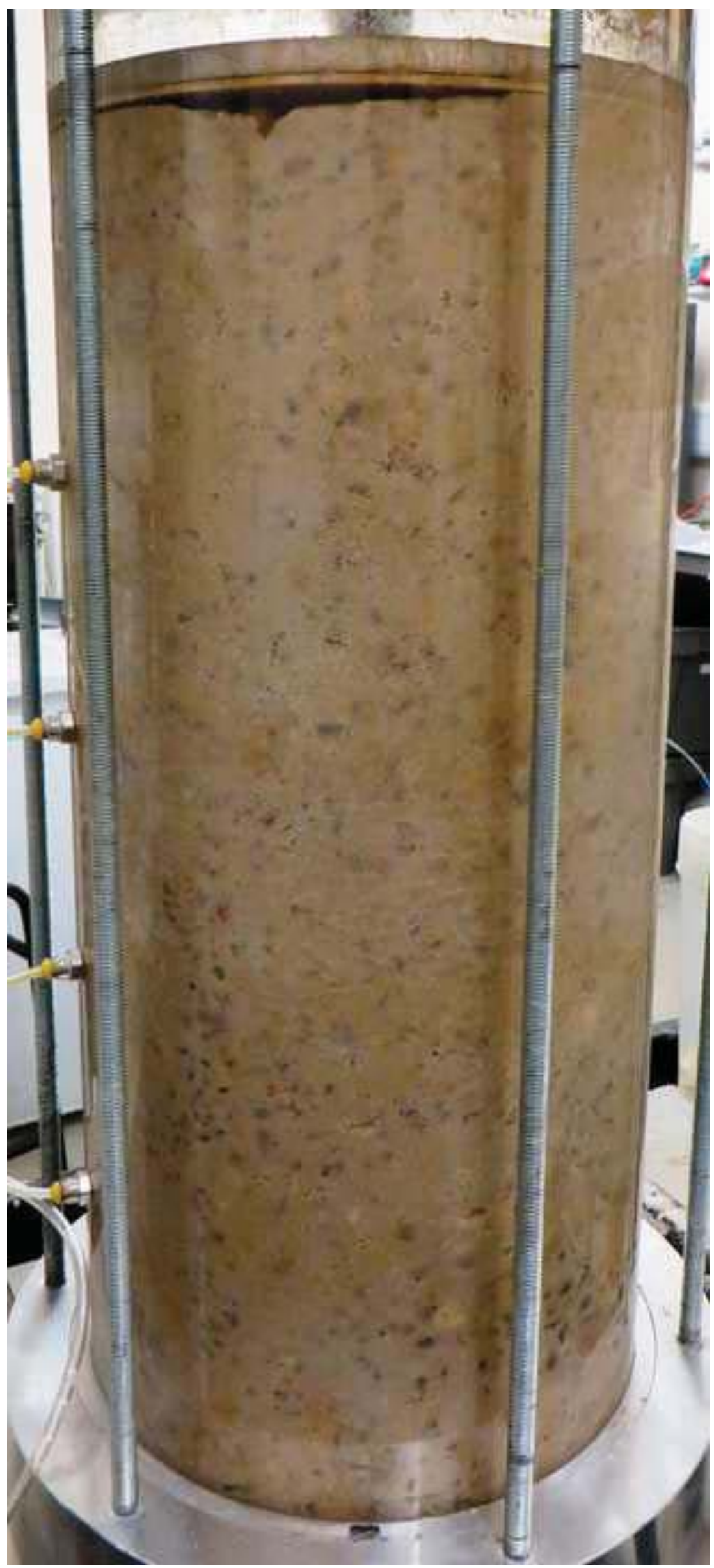




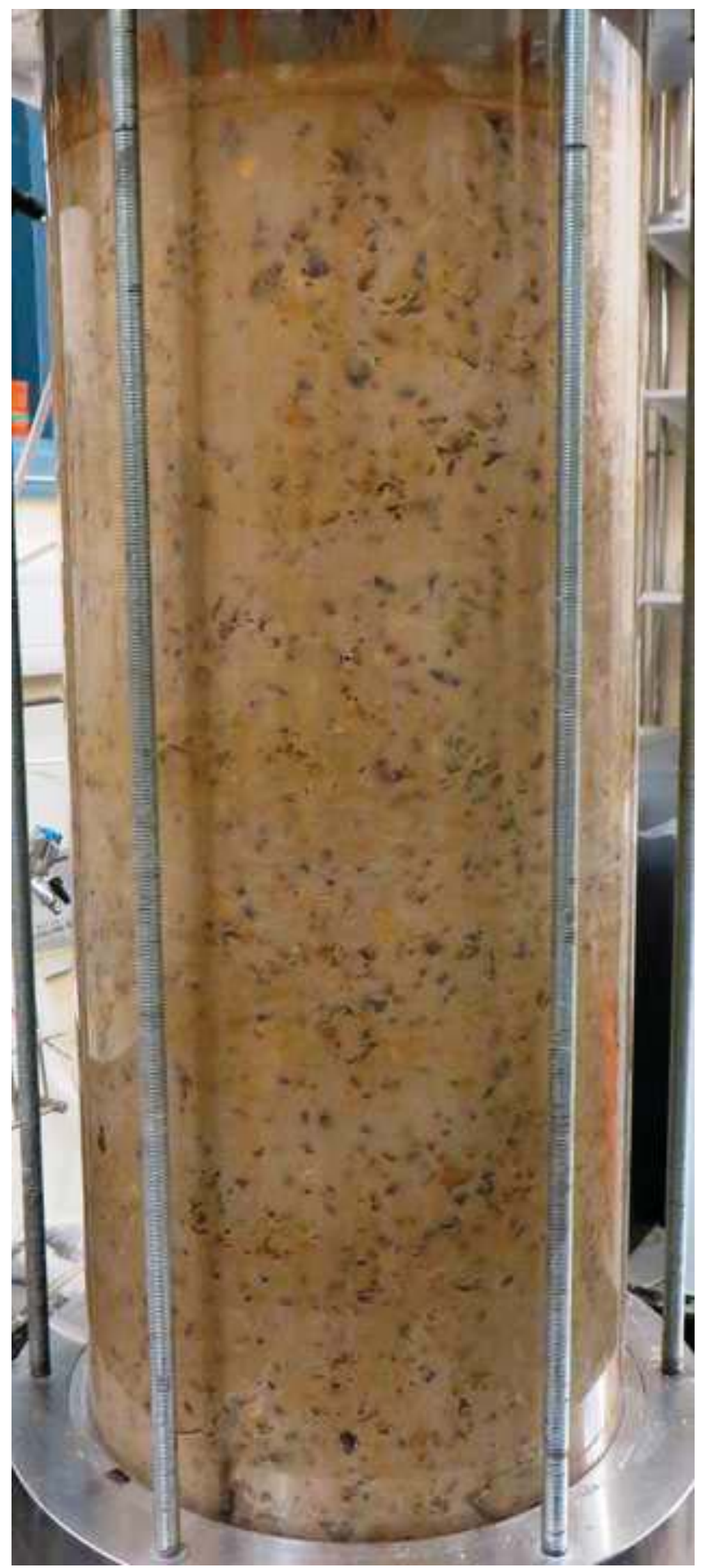




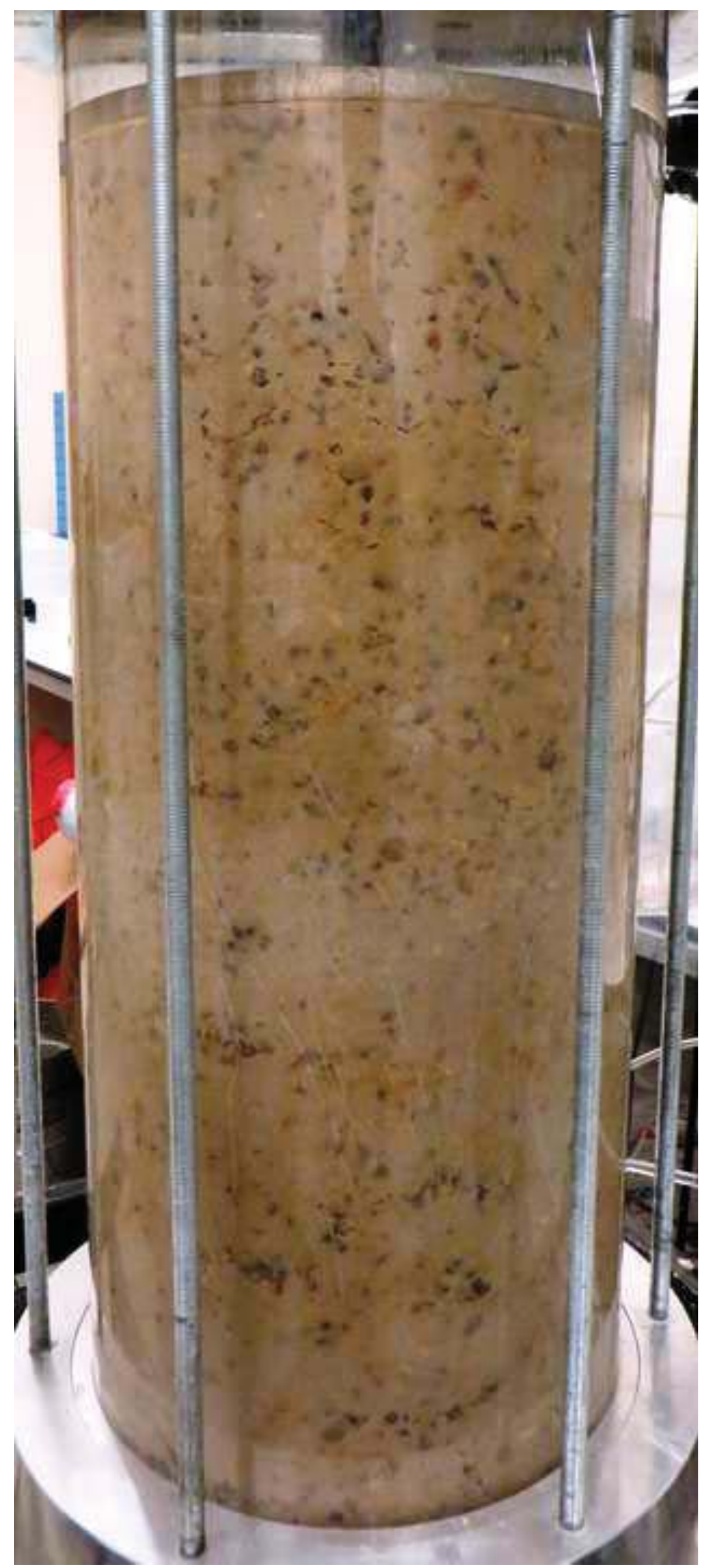




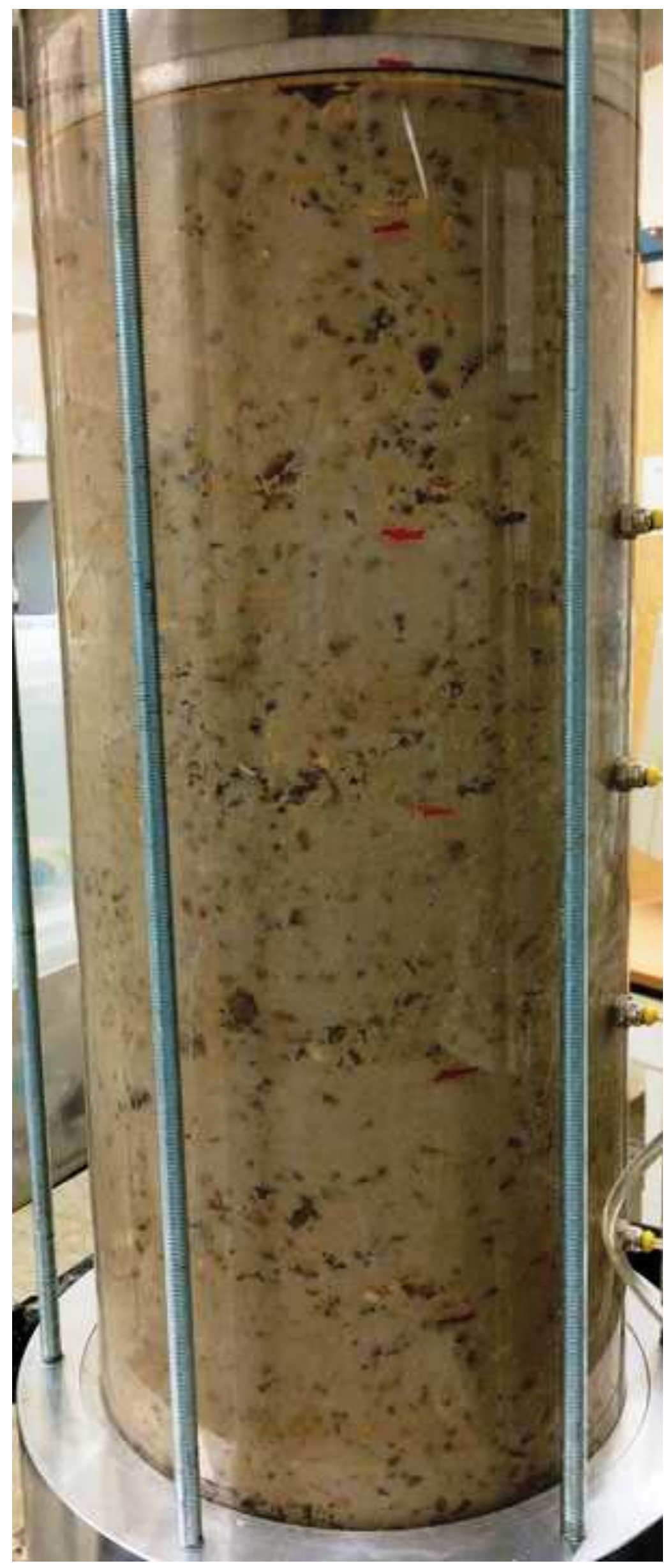




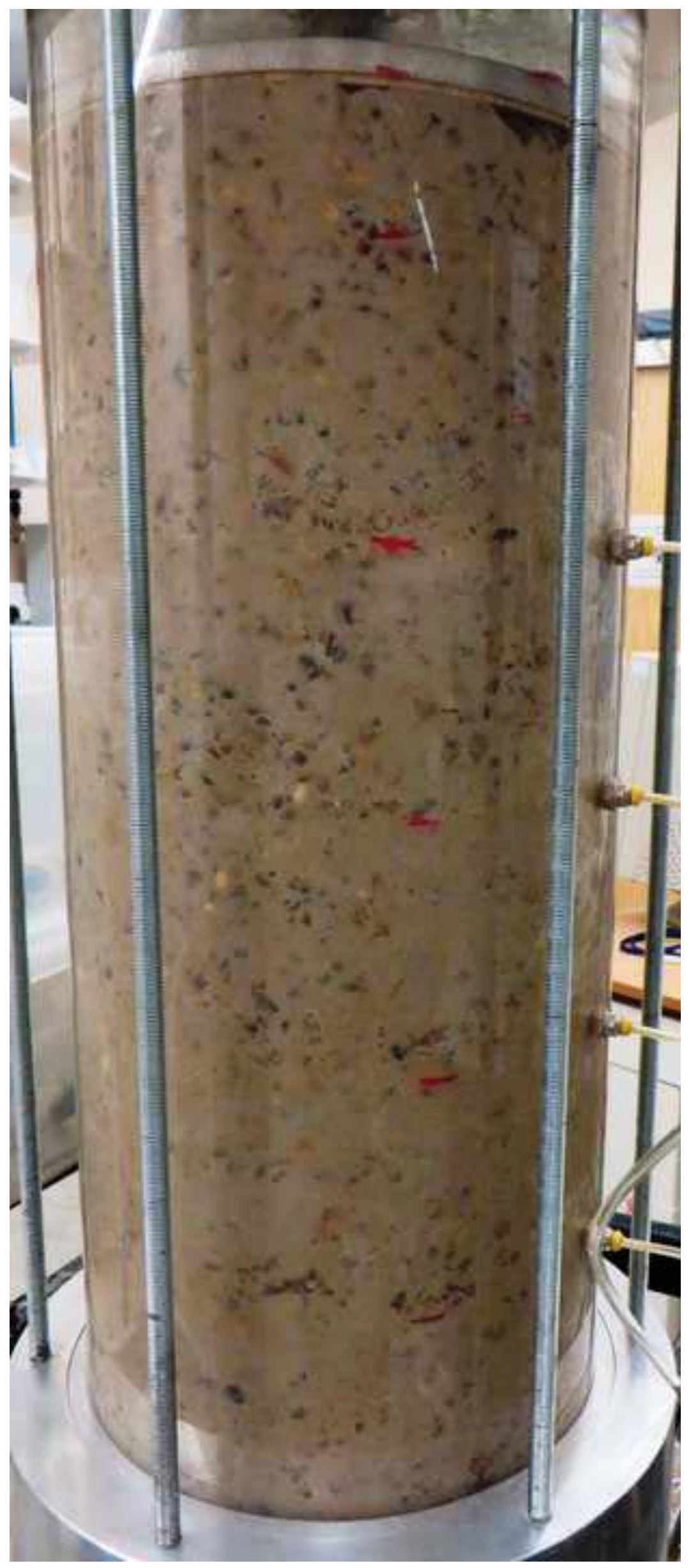



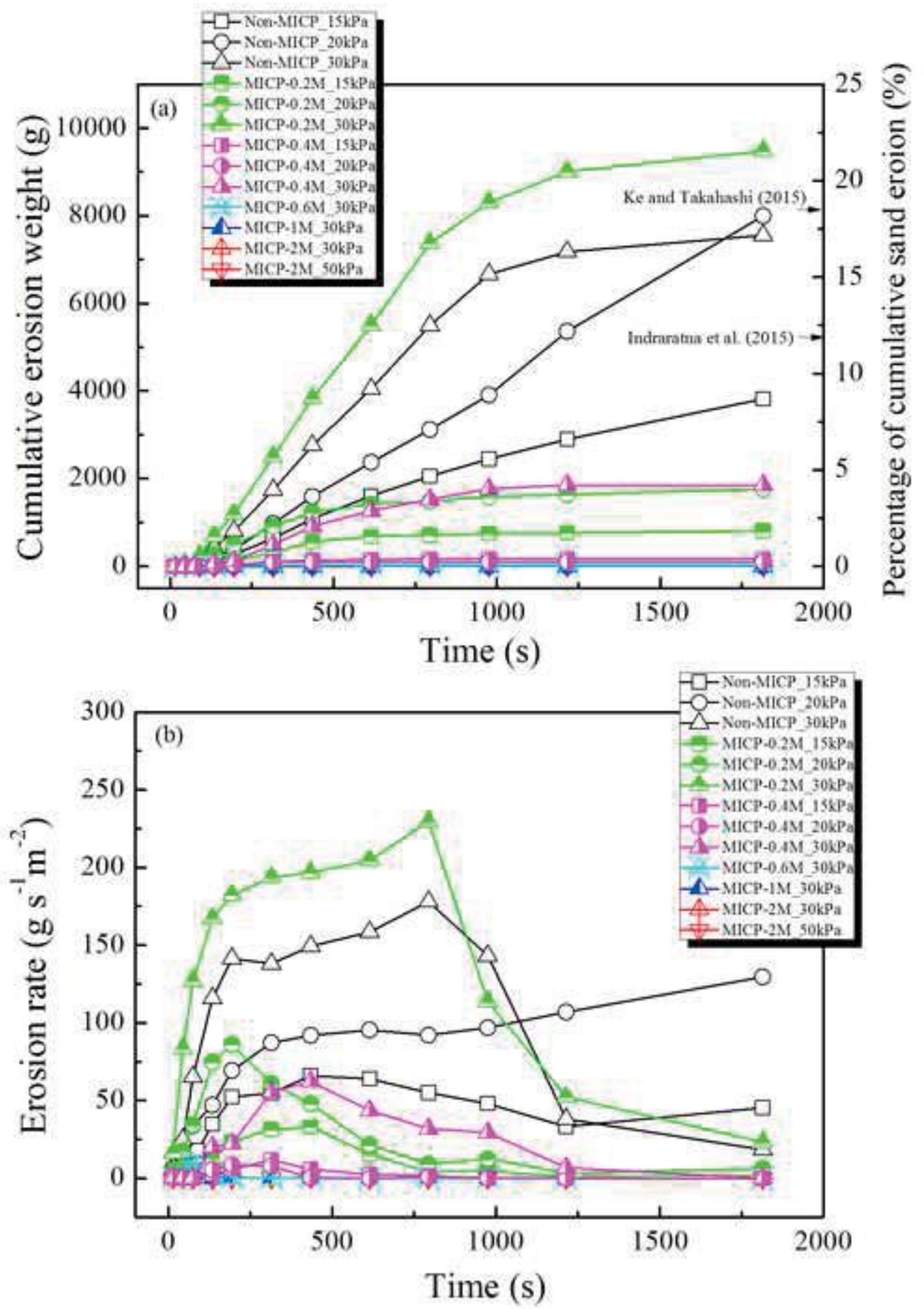


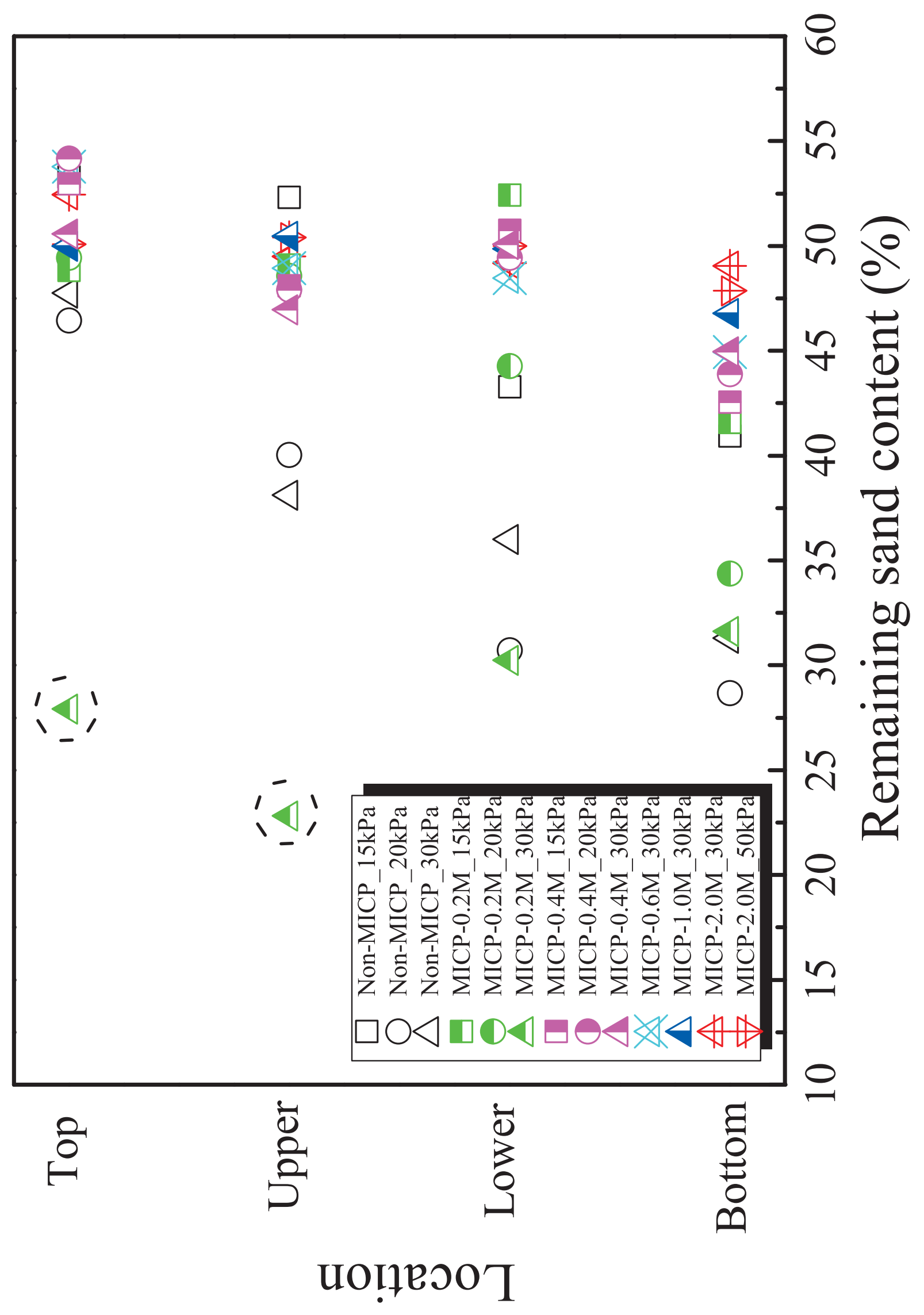



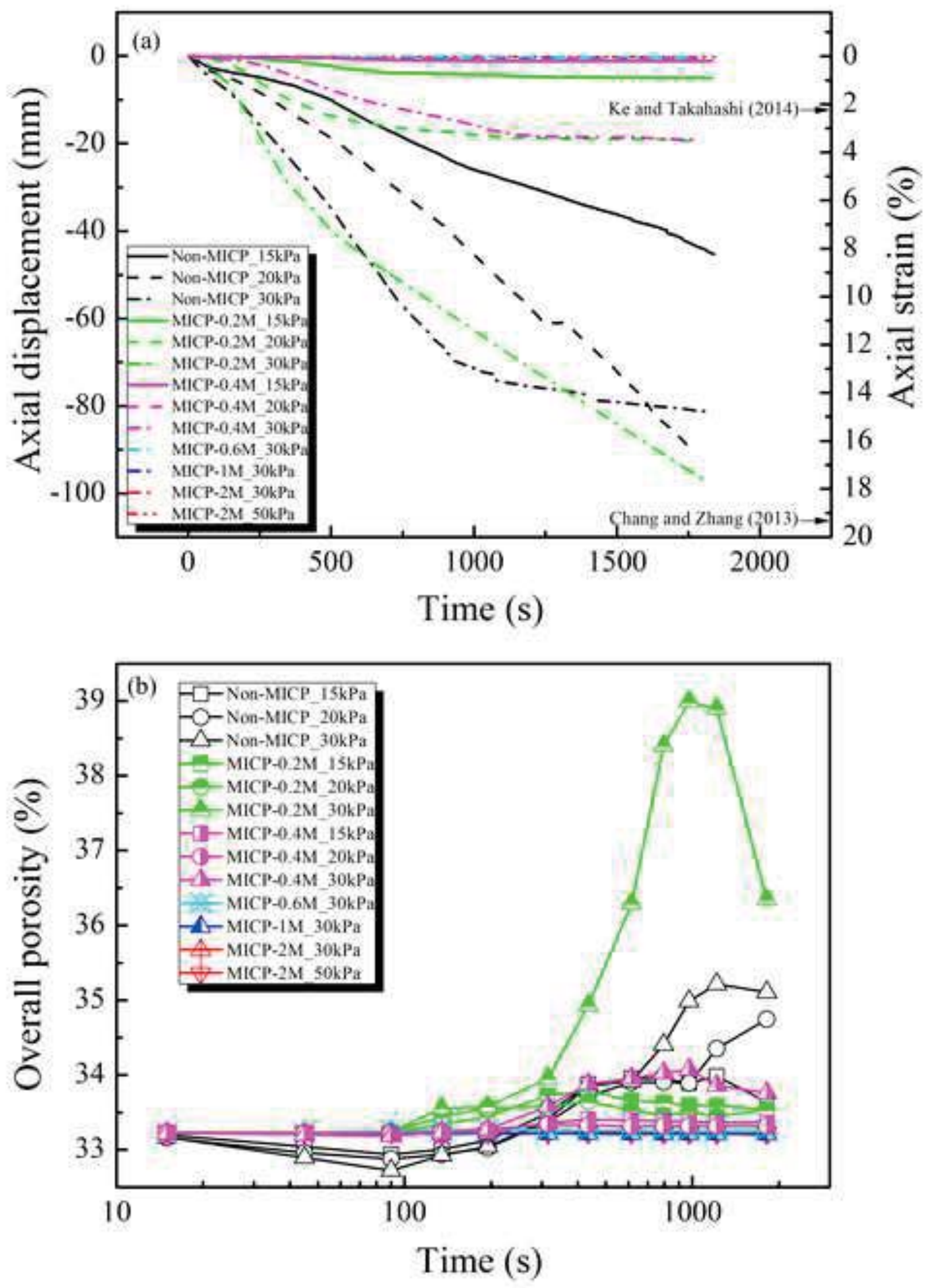


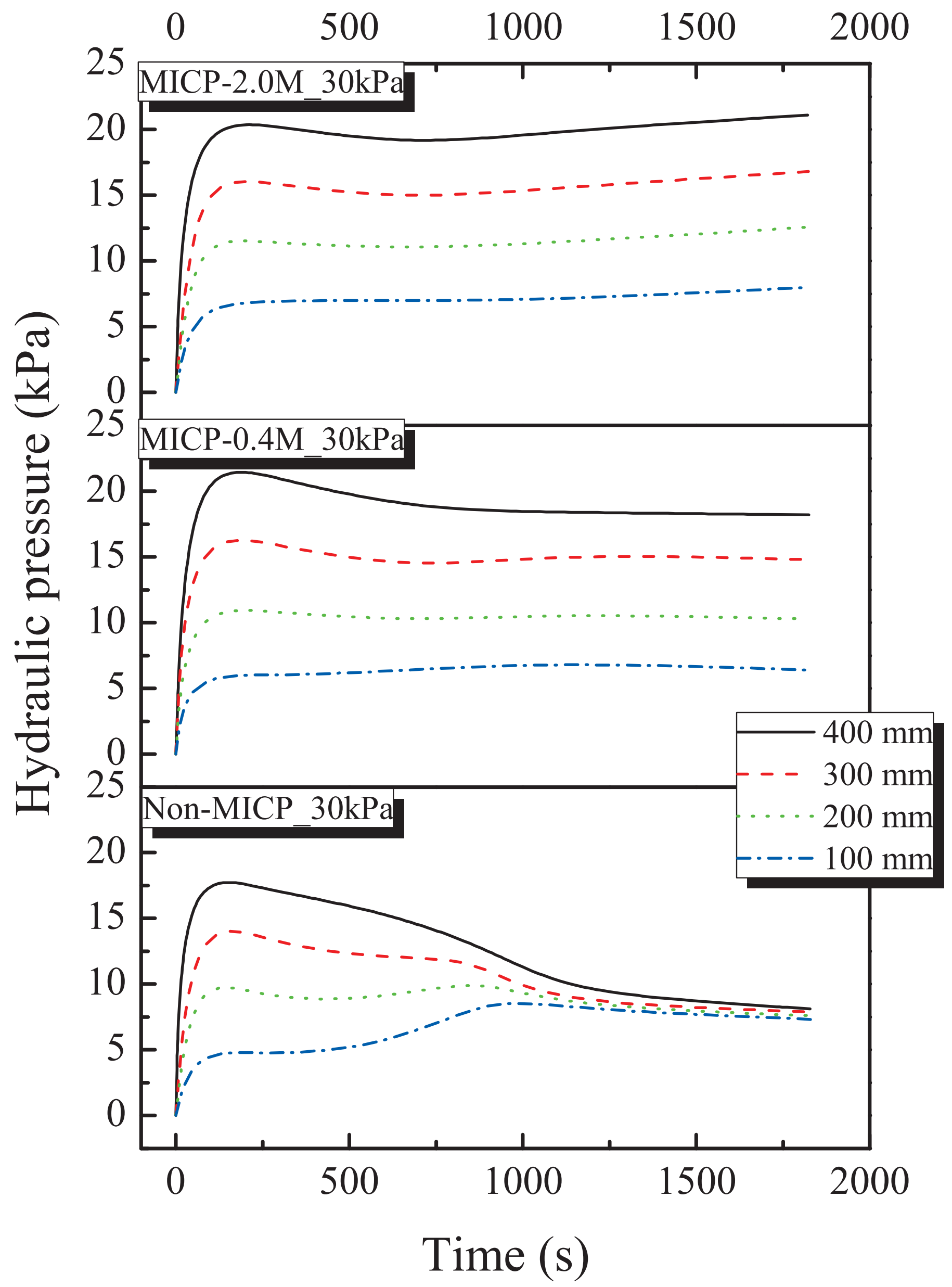




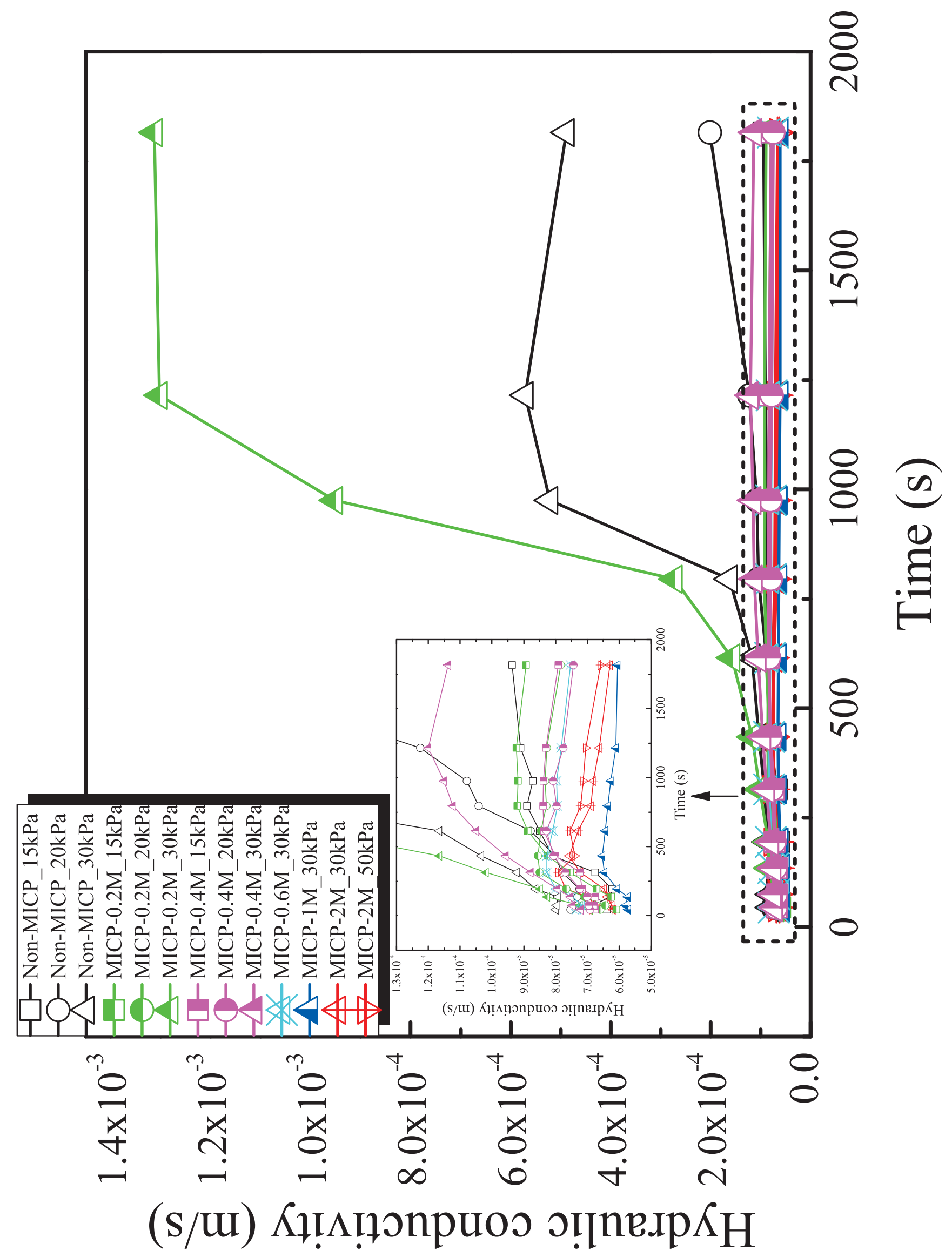




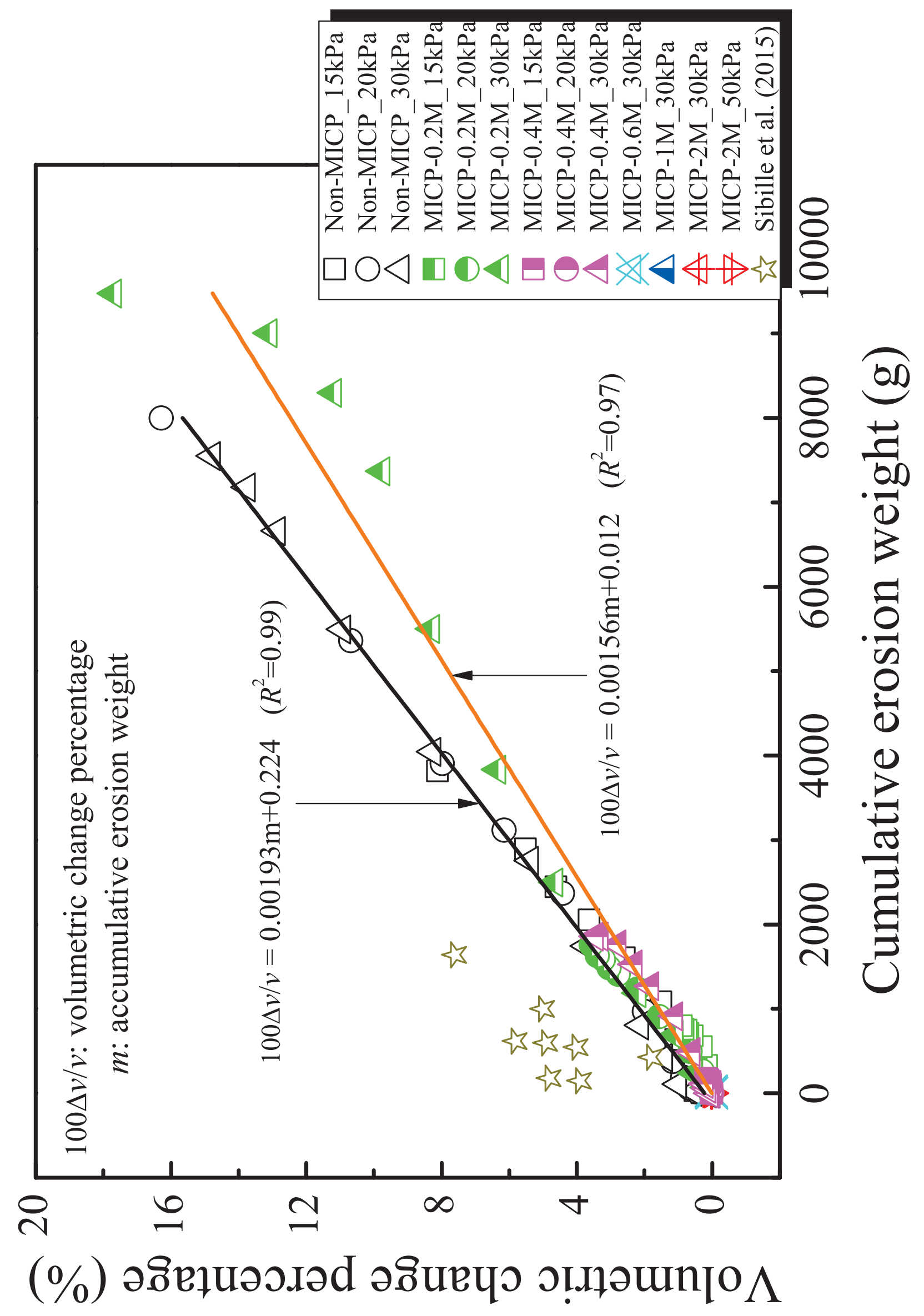




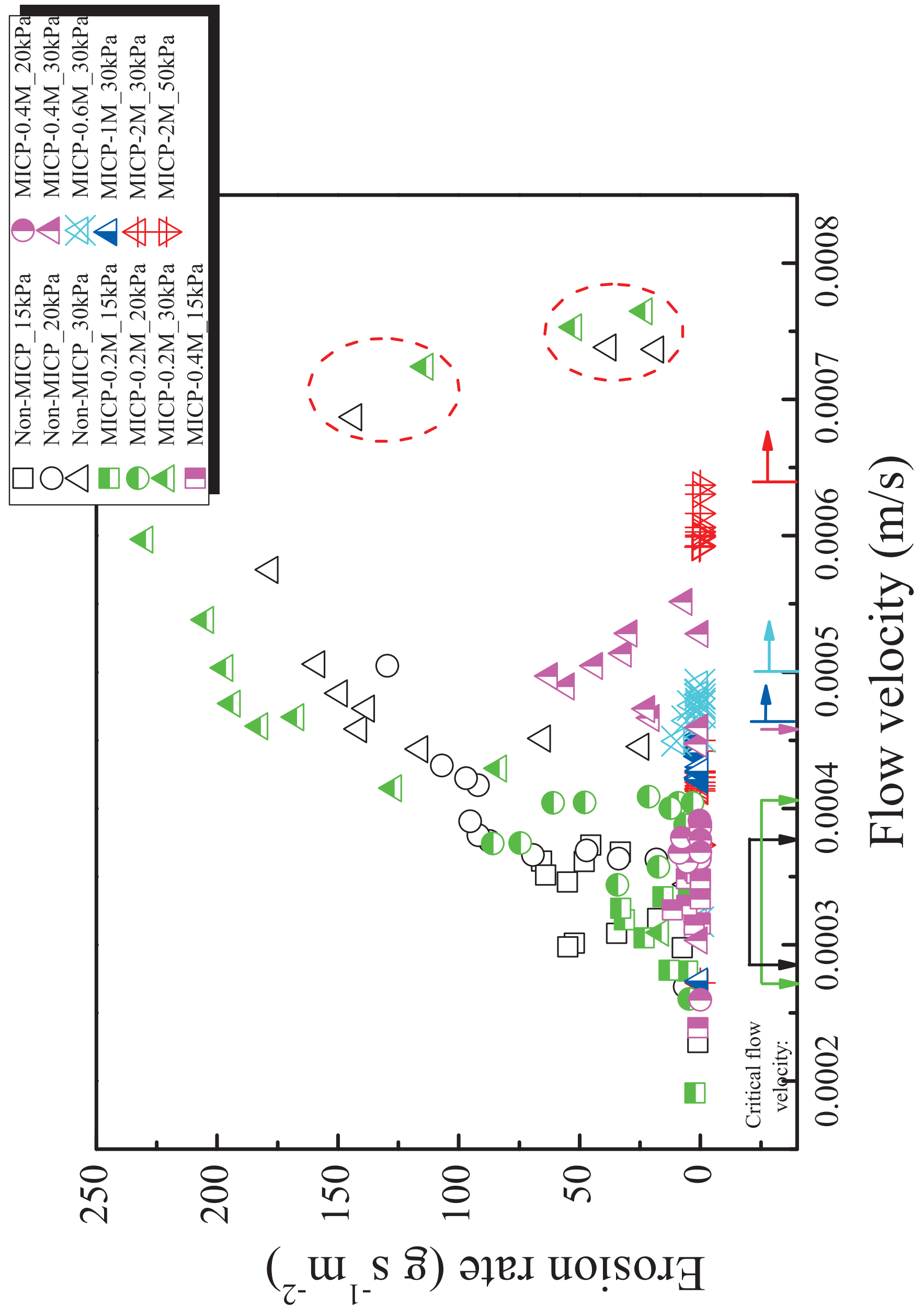




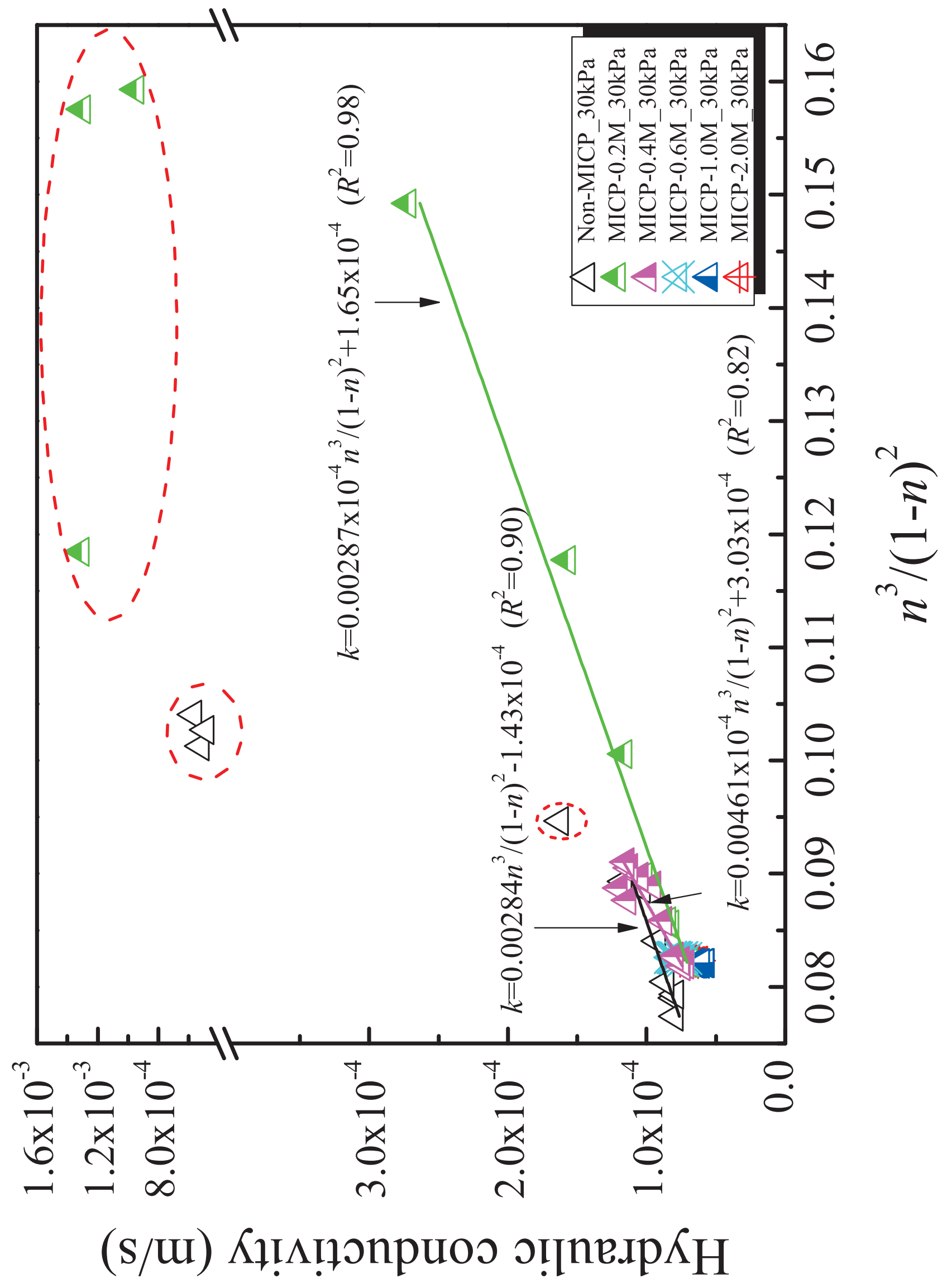




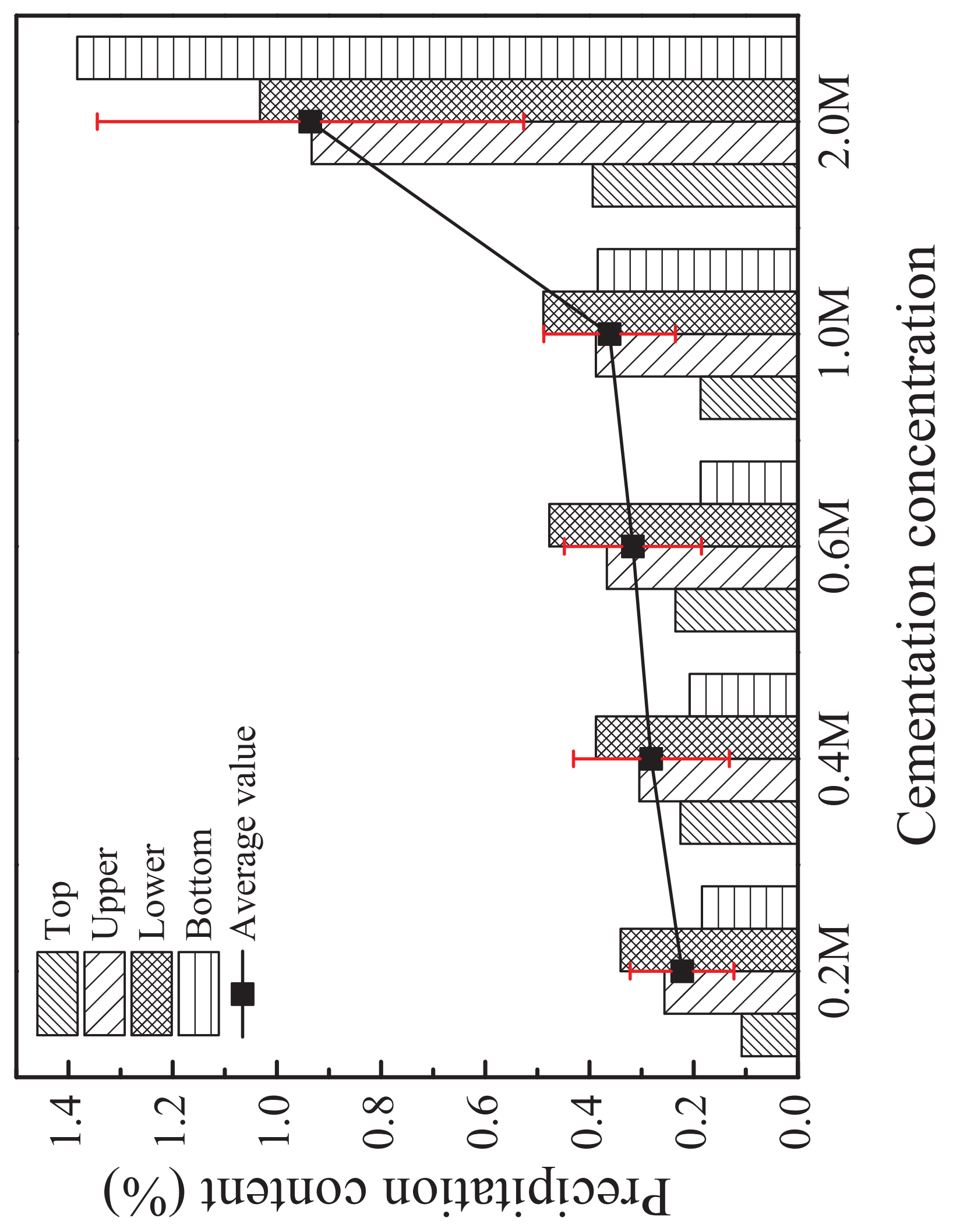




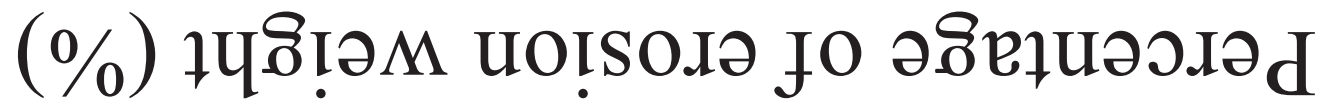

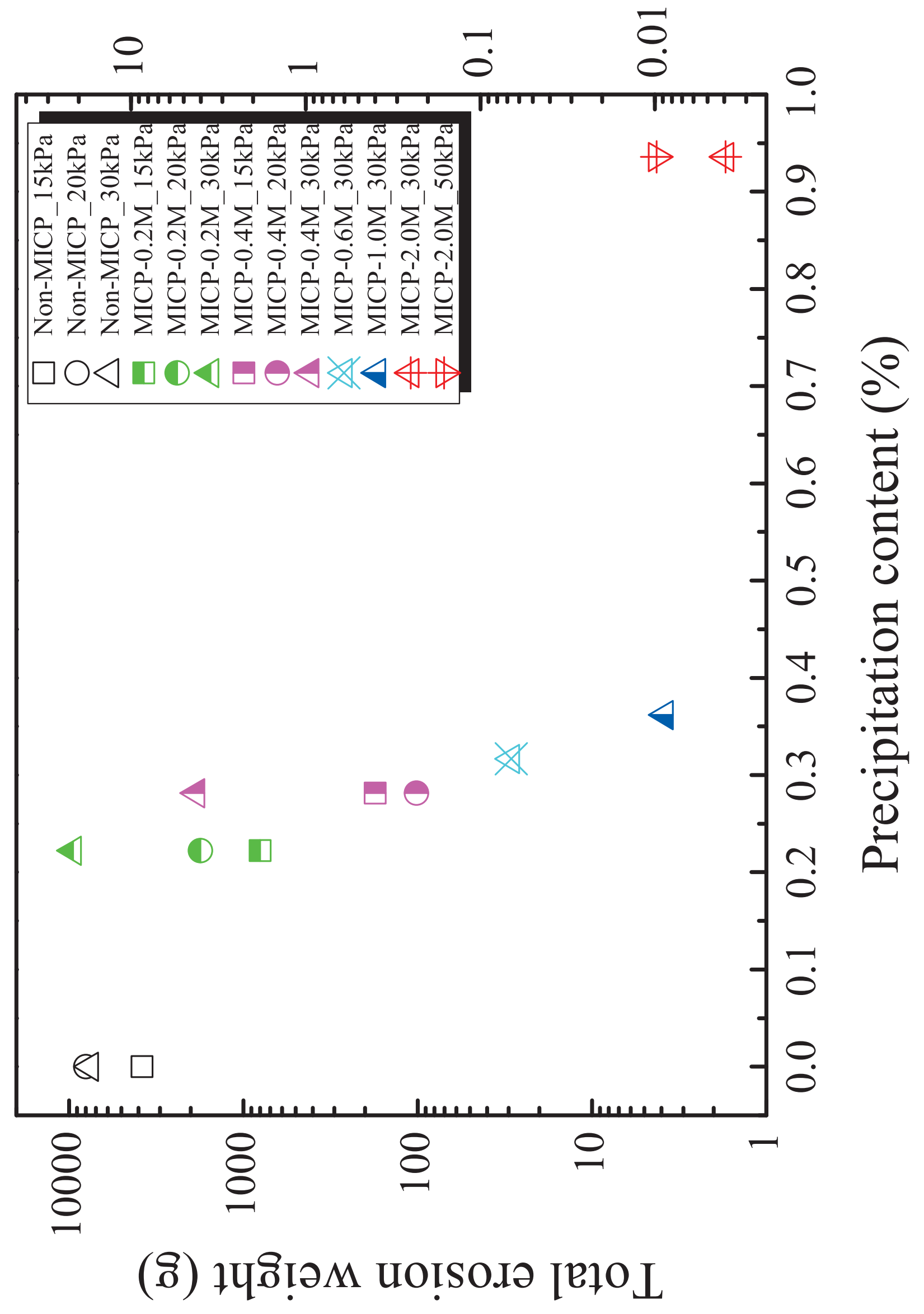




\section{Notation List}

$C$

composite pore shape factor

$D_{s} \quad$ characteristic grain size

$e \quad$ void ratio of the gravel-sand mixture

$G_{s g} \quad$ specific gravity of gravel

$G_{s s} \quad$ specific gravity of sand

$k \quad$ hydraulic conductivity of the gravel-sand mixture

$m_{g} \quad$ the weight of gravel in the gravel-sand mixture

$m_{s} \quad$ the weight of sand in the gravel-sand mixture

$n \quad$ overall porosity of the gravel-sand mixture

$S \quad$ degree of saturation

$V \quad$ total volume of the gravel-sand mixture

$V_{s} \quad$ volume of the soil grains in the gravel-sand mixture

$V_{v} \quad$ volume of voids in the gravel-sand mixture

$\rho_{w} \quad$ unit weight of water

$\mu \quad$ water viscosity 